\title{
The Natural History, Pathobiology, and Clinical Manifestations of SARS-CoV-2 Infections
}

\author{
Jatin Machhi ${ }^{1}$ - Jonathan Herskovitz ${ }^{1,2} \cdot$ Ahmed M. Senan $^{3} \cdot$ Debashis Dutta $^{4} \cdot$ Barnali Nath $^{5} \cdot$ Maxim D. Oleynikov ${ }^{1}$. \\ Wilson R. Blomberg ${ }^{1}$ • Douglas D. Meigs ${ }^{1}$ • Mahmudul Hasan ${ }^{6}$ • Milankumar Patel $^{1}$ • Peter Kline ${ }^{7}$. \\ Raymond Chuen-Chung Chang ${ }^{8} \cdot$ Linda Chang $^{9} \cdot$ Howard E. Gendelman ${ }^{1,2,6} \cdot$ Bhavesh D. Kevadiya ${ }^{1,10}$
}

Received: 1 July 2020 / Accepted: 8 July 2020 / Published online: 21 July 2020

(C) Springer Science+Business Media, LLC, part of Springer Nature 2020

\begin{abstract}
Severe acute respiratory syndrome coronavirus 2 (SARS-CoV-2) is the etiological agent of coronavirus disease 2019 (COVID-19). SARS-CoV-2, is a positive-sense single-stranded RNA virus with epithelial cell and respiratory system proclivity. Like its predecessor, SARS-CoV, COVID-19 can lead to life-threatening disease. Due to wide geographic impact affecting an extremely high proportion of the world population it was defined by the World Health Organization as a global public health pandemic. The infection is known to readily spread from person-to-person. This occurs through liquid droplets by cough, sneeze, hand-to-mouth-to-eye contact and through contaminated hard surfaces. Close human proximity accelerates SARS-CoV-2 spread. COVID-19 is a systemic disease that can move beyond the lungs by bloodbased dissemination to affect multiple organs. These organs include the kidney, liver, muscles, nervous system, and spleen. The primary cause of SARS-CoV-2 mortality is acute respiratory distress syndrome initiated by epithelial infection and alveolar macrophage activation in the lungs. The early cell-based portal for viral entry is through the angiotensin-converting enzyme 2 receptor. Viral origins are zoonotic with genomic linkages to the bat coronaviruses but without an identifiable intermediate animal reservoir. There are currently few therapeutic options, and while many are being tested, although none are effective in curtailing the death rates. There is no available vaccine yet. Intense global efforts have targeted research into a better understanding of the epidemiology, molecular biology, pharmacology, and pathobiology of SARS-CoV-2. These fields of study will provide the insights directed to curtailing this disease outbreak with intense international impact.
\end{abstract}

Keywords Severe acute respiratory syndrome coronavirus 2 (SARS-CoV-2) · Coronavirus disease 2019 (COVID-19) · Acute respiratory distress syndrome (ARDS) · Angiotensin-converting enzyme $2($ ACE-2)

Howard E. Gendelman

hegendel@unmc.edu

$\triangle$ Bhavesh D. Kevadiya

kevadiya@stanford.edu

1 Department of Pharmacology and Experimental Neuroscience, College of Medicine, University of Nebraska Medical Center, Omaha, NE 68198-5880, USA

2 Department of Pathology and Microbiology, College of Medicine, University of Nebraska Medical Center, Omaha, NE 68198, USA

3 Glycomics and Glycan Bioengineering Research Center (GGBRC), College of Food Science and Technology, Nanjing Agricultural University, Nanjing 20095, China

4 Department of Immunology and Microbiology, The Scripps Research Institute, Jupiter, FL 33458, USA
5 Viral Immunology Lab, Indian Institute of Technology Guwahati, Guwahati, Assam 781039, India

6 Department of Pharmaceutical Sciences, College of Pharmacy, University of Nebraska Medical Center, Omaha, NE 68198, USA

7 SARS-CoV-2 Patient Survivor, Chicago, IL 60204, USA

8 Laboratory of Neurodegenerative Diseases, School of Biomedical Sciences, LKS Faculty of Medicine, and State Key Laboratory of Brain and Cognitive Sciences, The University of Hong Kong, Hong Kong, SAR, China

9 University of Maryland, School of Medicine, Baltimore, MD 21201, USA

10 Interventional Regenerative Medicine and Imaging Laboratory, Department of Radiology, Stanford University, Palo Alto, CA 94304, USA 


$\begin{array}{ll}\text { Abbreviations } & \\ \text { ACE-2 } & \text { Angiotensin-converting enzyme 2 } \\ \text { ARDS } & \text { Acute respiratory distress syndrome } \\ \text { BBB } & \text { Blood-brain-barrier } \\ \text { CNS } & \text { Central nervous system } \\ \text { COVID-19 } & \text { Coronavirus disease 2019 } \\ \text { CSF } & \text { Cerebrospinal fluid } \\ \text { CSG } & \text { Coronavirus Study Group } \\ \text { DMVs } & \text { Double-membrane vesicles } \\ \text { ER } & \text { Endoplasmic reticulum } \\ \text { ERGIC } & \text { ER-Golgi intermediate compartment } \\ \text { FMT } & \text { Fecal microbiota } \\ \text { GBS } & \text { Guillain-Barre Syndrome } \\ \text { GI } & \text { Gastrointestinal } \\ \text { GSK3 } & \text { Glycogen synthase kinase 3 } \\ \text { IBV } & \text { Infectious bronchitis virus } \\ \text { MERS } & \text { Middle East respiratory syndrome } \\ \text { MHV } & \text { Mouse hepatitis virus } \\ \text { NLR } & \text { Neutrophil-to-lymphocyte ratio } \\ \text { PLPro } & \text { Papain-like protease } \\ \text { PPE } & \text { Personal protective equipment } \\ \text { RBD } & \text { Receptor binding domain } \\ \text { RdRP } & \text { RNA-dependent RNA polymerase } \\ \text { SARS-CoV } & \text { Severe acute respiratory } \\ & \text { syndrome coronavirus } \\ \text { SARS-CoV-2 } & \text { Severe acute respiratory syndrome } \\ \text { sgRNA } & \text { coronavirus 2 } \\ \text { SDOH } & \text { Subgenomic RNA } \\ \text { TGEV } & \text { Social determinants of health } \\ \text { WHO } & \text { Transmissible gastroenteritis virus } \\ \text { World Health Organization }\end{array}$

\section{Defining the Global Pandemic}

The impact of the global coronavirus pandemic is evident in its rapid disease spread. The virus has reached nearly every country worldwide in less than 6 months. Several of these countries are already enduring a second wave outbreaks, while others such as Russia, Brazil, India, and select parts of Africa, remain in their first wave (Dong et al. 2020a; Wu et al. 2020b; $\mathrm{Xu}$ and $\mathrm{Li}$ 2020). The etiological agent was named severe acute respiratory syndrome coronavirus 2 (SARS-CoV-2) on February 11th, 2020, by the World Health Organization (WHO) (Gorbalenya et al. 2020; Zhu et al. 2020b). SARSCoV-2, the cause of coronavirus 2019 (COVID-19) disease, belongs to the same family of viruses as severe acute respiratory syndrome coronavirus (SARS-CoV) and the Middle East respiratory syndrome coronavirus (MERS-CoV), respectively named in 2003 and 2012. However, unlike those preceding novel coronavirus-linked diseases, the COVID-19 pandemic resulted in considerably greater morbidities and mortality (Dong et al. 2020a; Zhu et al. 2020b). The greater societal penetration of SARS-CoV-2 arises from its increased viral spread through asymptomatic or presymptomatic carriers who serve as a nidus for rapid disease spread (de Wit et al. 2016; Gandhi et al. 2020). First detected in Wuhan, the capital city of Hubei, China, in December of 2019 (Dong et al. 2020a), SARS-CoV-2 has spread throughout the world by travel and community-based contacts (WHO 2020a; Wu et al. 2020b; Zhu et al. 2020a).

The virus was quickly identified as a coronavirus sharing genomic homology with SARS-CoV-1 (Lu et al. 2020a; Wan et al. 2020). Due to its rapid global spread, it was named "the first pandemic of the 21st century" by the WHO (Dong et al. 2020a; WHO 2020a). This reflected its continent-to-continent spread and a high case fatality (Wu et al. 2020b; Zhu et al. 2020a). Due of the rapid SARS-CoV-2 person-to-person infectious spread, the ability to provide rapid, sensitive and specific diagnostic and serological testing has proven paramount for the management and prevention of COVID-19 spread. Although testing technologies have been quick to respond, therapeutic interventions, including pharmacologic and immune-modulatory strategies for controlling disease spread and speeding patient recovery are urgently needed (WHO 2020a; Tao et al. 2020). While the United States was slow in efforts to meet testing demand, rapid responses were recorded in China, South Korea, Australia, and New Zealand (Dong et al. 2020a; WHO 2020a, b). SARS-CoV-2 has infected more than 12.7 million people globally and killed more than 560,000 with those numbers ever increasing (Dong et al. 2020a). The current pandemic has affected nearly every part of society, transforming our daily habits, lifestyle, work, family, and social cultures (Wu et al. 2020b; Zhu et al. 2020a).

\section{Epidemiology}

On February 11th, 2020, the Coronaviridae Study Group of International Committee on Taxonomy of Viruses named the novel beta coronavirus as SARS-CoV-2 based on phylogenetic tests (Gorbalenya et al. 2020). The SARS-CoV-2 has a genome size of $\sim 30,000$ base (Cui et al. 2019a; Britannica 2020; $\mathrm{Lu}$ et al. 2020a; Wrapp et al. 2020) belonging to the family Coronaviridae, of the order Nidovirales. It is classified into alpha, beta, gamma, and delta coronaviruses by phylogenetic clustering (Woo et al. 2010; de Groot et al. 2013; Lefkowitz et al. 2018). Alpha- and betacoronaviruses primarily infect mammals, humans included, whereas gamma and delta coronaviruses infect birds (Wertheim et al. 2013). There are seven known human coronaviruses (Cui et al. 2019b; Gorbalenya et al. 2020). The genus alpha- and betacoronavirus consist of the human coronaviruses $\mathrm{HCoV}$ 229E, HCoV-NL63, HCoV-OC43, and HCoV-HKU1. Other beta family members include SARS-CoV-1 and MERS-CoV (Woo et al. 2010; Lim et al. 2016; Zumla et al. 2016). Nearly 
50 years ago, the human coronaviruses $\mathrm{HCoV}-\mathrm{OC} 43$ and HCoV-229E were identified, which are among the pathogens responsible for the common cold (Zhang et al. 2018). HCoVNL63 and HCoV-HKU1, discovered in the wake of the SARS epidemic, cause mild respiratory tract infections (de Groot et al. 2013; Zumla et al. 2016).

Additionally, each of the human coronaviruses can lead to severe lower respiratory tract infections. The disease affects all age groups and is exacerbated in individuals with underlying comorbid diseases (Pyrc et al. 2007; Zhang et al. 2018). SARS-CoV and MERS-CoV are zoonotic in origin, highly pathogenic and have led to disease epidemics over the last two decades (Fehr and Perlman 2015; de Wit et al. 2016). SARS-CoV was first identified in Guangdong, China, in February 2003. The infection spread to 29 countries during the time period from November 2002 to July 2003. There were 8096 confirmed cases and 774 deaths, with a case fatality rate of $9.6 \%$ (WHO 2003). SARS-CoV was contained and no new cases were reported since 2004 (Kimberlin et al. 2018). The MERS-CoV was first identified in Jeddah, Saudi Arabia, in 2012 (Zaki et al. 2012). This virus was also previously unknown, with an outbreak in the Arabian Peninsula, which spread to 27 countries in April 2012 (Kimberlin et al. 2018). To date, MERS-CoV has infected 2502 people with 861 deaths, with a case fatality rate of $34.4 \%$ (WHO 2019). For both the SARS-CoV and MERS coronaviruses, bats are the natural hosts (Luk et al. 2019; Zhou et al. 2020c). The viruses enter the human population through intermediate hosts. For SARS, the prominent intermediate hosts are civet cats, though presumably other animals are not yet identified. For MERS, the intermediate hosts are dromedary camels (Coleman and Frieman 2014; Mackay and Arden 2015; Wong et al. 2019; Ye et al. 2020b). Coronaviruses transmission from bats to intermediate hosts allows for multiple rounds of replication and mutations before human transmission (Bolles et al. 2011; Wong et al. 2019).

In December 2019, sequencing of the fluid samples collected from a cluster of patients with pneumonia identified the causal agent as a novel coronavirus (Zhu et al. 2020a, b), and soon the virus was named as SARS-CoV-2 (Zhu et al. 2020a, b). Prior to 2002, coronaviruses were considered exclusively veterinary pathogens. They are now considered a causative agent of human respiratory pathogens as demonstrated during 2002-2003, 2012 and 2019 from the outbreaks of SARS, MERS and COVID-19, respectively (Coleman and Frieman 2014; Siddamreddy et al. 2020). A Bayesian phylogenetic analysis of SARS-CoV-2 used 53 whole-genome viral sequences to estimate the most recent common ancestor. This showed that December 13th, 2019, was the day when the virus was introduced into the human population with a $95 \%$ confidence interval (CI). The doubling time of the epidemic was at 7.1 days, with a $95 \%$ CI (Volz et al. 2020).
The evolution of SARS-CoV-2 is based on its phylogenetic and taxonomic features, speculated from the family of coronaviruses with a higher resemblance to SARS-CoV, as suggested by Coronavirus Study Group (CSG) (Gorbalenya et al. 2020). The ages of infected people range from a 4 week old to $>90$ years, although fewer cases were reported in children and infants (Dong et al. 2020b; Lu et al. 2020b). The highest population is averaged at 55.5 years of age (Chen et al. 2020b). Males represent 59-68\% of reported cases (Chen et al. 2020b; Li et al. 2020a). However, elderly individuals ( $>75$ years) have much higher mortality rates (Wang et al. 2020c). Populations most susceptible to infection and complications are the elderly (Wang et al. 2020a) and those with poor immune function ( $\mathrm{Li}$ et al. 2020a; Liu et al. 2020). Individuals taking immunosuppressive agents (Chen et al. 2020a), have hypertension, or have recently undergone surgeries are also at risk (Wang et al. 2020a). On March 21st, 2020, the case fatality rate was reported in China at 3.85\% (Spychalski et al. 2020). The incubation period of SARS-CoV-2 ranges from 2 to 14 days, and the basic reproduction number $\left(\mathrm{R}_{0}\right)$ ranges from 1.5-4.92 (Backer et al. 2020; Li et al. 2020a; Read et al. 2020; Riou and Althaus 2020; Shen et al. 2020; Wu et al. 2020b). The mean incubation period of SARS-CoV-2 parallels SARS-CoV: 5 days, with a range of 2 to 14 days. For MERS, the mean incubation period is also 5 to 7 days, with a range of 2 to 14 days. Non-SARS human coronavirus infections show a mean incubation period of 3 days and a range of 2 to 5 days. Knowledge of the incubation period allows for accurate monitoring, surveillance, and disease control (Lauer et al. 2020). The understanding of COVID-19 disease is quickly evolving, with new information published nearly daily (Dong et al. 2020a). The pandemic of COVID-19 is most severe in the USA, though it was not the first country to be severely impacted. After its initial devastation in Wuhan, China, SARS-CoV-2 spread quickly to Italy, the United Kingdom, and France (Dong et al. 2020a).

\section{Natural History}

It is important to revisit the past pandemics of SARS-CoV and MERS, due to the structural and molecular similarities between these viruses and SARS-CoV-2. Historically, SARS originated in Guangdong, China, then spread to Hong Kong, infected 1755 people with 299 deaths, and caused an economic downturn (Hung 2003; WHO 2003). The mortality rate in Hong Kong was $17 \%$, compared to $11 \%$ worldwide. Disease signs and symptoms paralleled what we now see in COVID19 (2020a) with shortness of breath, cough and chest pain, progressing to respiratory distress and the acute respiratory distress syndrome (ARDS) (Hung et al. 2003; Hung 2003; Chen et al. 2020a). People were expected to wear a mask 
and keep social distances. Those with close infectious contact were quarantined for 14 days whether or not they showed any symptoms (Abdullah et al. 2003; Hung 2003). With these precautions and frequent, vigorous hand washings, control over the viral spread was achieved (Abdullah et al. 2003; Hung 2003).

MERS symptoms are similar to SARS, in which fever, cough, shortness of breath, and pneumonia are common (Zaki et al. 2012). The outbreak was limited to several countries, which included Saudi Arabia, the United Arab Emirates, and Korea (Cho et al. 2016). However, the death rate reached $35 \%$, according to $\mathrm{WHO}$, with camels as a primary host for transmission to humans. Precautions mimicked what was advised for SARS with the caveat that people were also advised to avoid contact with camels, drink raw camel milk, or eat uncooked camel meat (Mackay and Arden 2015). The impact of MERS to European and American societies was minimal. However, infection of MERS continues to occur in Middle Eastern countries today (Mackay and Arden 2015; WHO 2019).

On December 31st, 2019, the WHO China Country Office was informed of a sudden increase in cases of pneumonia in Wuhan City, Hubei Province. By January 5th, 2020, a total of 44 patients, with 11 severely ill, were attributed to an unidentified pathogen (WHO 2020c). Two days later, on January 7th, the WHO announced that they had identified a new coronavirus (WHO 2020d). On January 13th, the first reported case outside of China was identified in Thailand (WHO 2020e). By the end of the month, on January 30th, the WHO reported 7818 cases globally, affecting 18 countries and with 170 deaths in China (WHO 2020a, f).

February 9th marked a spike in the death toll with 910 dead and 40,000 cases in China alone (WHO 2020g). Deaths quickly overtook that of the 2002-03 SARS epidemic (WHO 2020g). On February 11th, the International Committee on Taxonomy of Viruses named the new coronavirus SARSCoV-2, based on the genetic similarity to SARS-CoV (WHO 2020h). On February 15th, Egypt and France reported deaths due to COVID-19 (WHO 2020i). By the end of February, 11 additional European countries reported cases with 82,000 confirmed infections and 2800 people killed worldwide (WHO $2020 \mathrm{j}$ ). On March 11th, the WHO officially declared the outbreak a pandemic, and governments across the world began implementing strategies to slow the infection spread, including social distancing and complete lockdown (WHO 2020b, k). On March 16th, no more new cases were reported in China, but by March 19th the death toll surpassed 10,000 worldwide (WHO 20201; Worldometer 2020a). Italy quickly became the new emerging epicenter with peak daily new cases reported at 6557 on March 21st (WHO 2020m; Worldometer 2020b). The infection quickly spread in the United States, with at least 100,000 cumulative cases by March 27th, and over 2700 deaths. On March 29th, the global number of cases surged to $>600,000$, including more than 29,000 deaths (WHO 2020n, o; Worldometer 2020c). On March 29th, Spain recorded 838 new deaths in $24 \mathrm{~h}$ (WHO 2020o; Worldometer 2020d). By March's end, few countries with unreported cases remained. The death toll in the United States surpassed that in China, and the international community had begun an unprecedented lockdown (Dong et al. 2020a; WHO 2020a).

April 1st brought a worldwide number of confirmed cases to 1 million with the death toll reaching 50,000 (WHO 2020p). On April 5th, Iran, the Middle East's most affected country, reported a death toll of 3603 out of 58,226 cases, a mortality rate of $6.2 \%$ (WHO 2020q; Worldometer 2020a). Just a little more than 1 week later, the United Kingdom witnessed its worst single-day spike with 980 deaths in 1 day (Worldometer 2020e). By midApril, the confirmed cases in the United States had swelled to over half a million (WHO 2020r). By the end of April, the death toll in the United States surpassed 50,000 , with the number of confirmed cases approaching 1 million, despite a lockdown in the majority of the States. In parallel, Turkey reported a total of 86,306 cases, surpassing Iran, as the country with the highest number of infections in the Middle East (Worldometer 2020a). Late April saw falling numbers for the countries first affected by the pandemic; on April 20th, Italy reported its lowest number of deaths in a week while recording its first drop in cases (Worldometer 2020b). On April 25th, China reported no new deaths in 10 consecutive days, but the number of deaths globally had surpassed 200,000 (WHO 2020s; Worldometer 2020a). April 27th marked 3 million worldwide confirmed cases (WHO 2020t), and the tally surpassed 5 million by May 25th (WHO 2020u) (Fig. 1). As of July 12 th, more than 12.7 million COVID-19 infections are confirmed in 213 countries and territories, including more than 560,000 deaths, with the highest proportion of cases and mortality in the United States (WHO 2020v). Throughout the world, the end of May was marked by social disturbances, economic downturn, and yearning for recovery (Dietz et al. 2020; CDC 2020a). While Italy, China, and South Korea showed sustained decreases in daily new cases, the United States' new infection rates continued to climb. New cases did not begin trending downward until May in the United States (WHO 2020a; Worldometer 2020a) and has again risen to record numbers since many states reopened.

\section{SARS-CoV-2}

SARS-CoV-2 is a highly pathogenic member of the coronavirus family. Due to the high mortality rate of the COVID-19 pandemic, understanding the molecular 


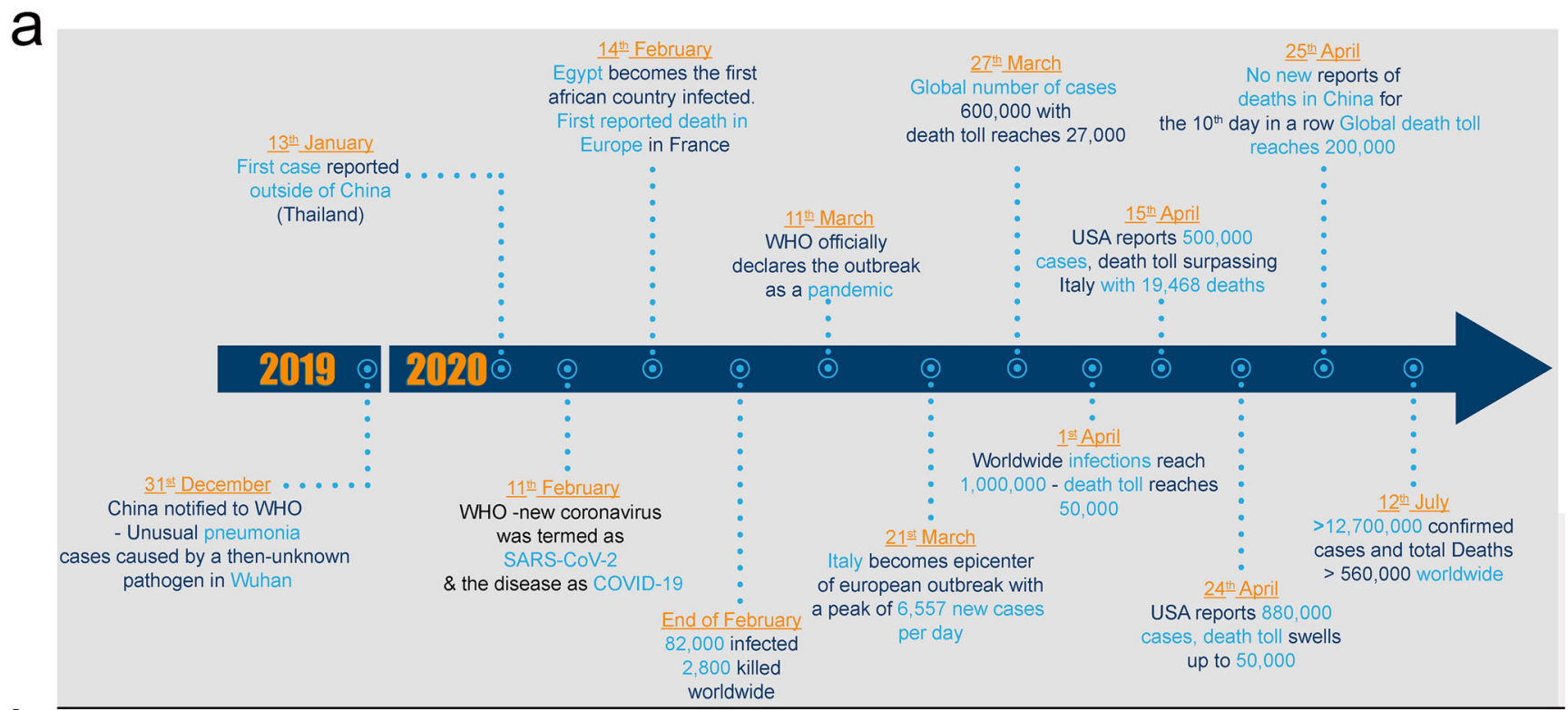

b
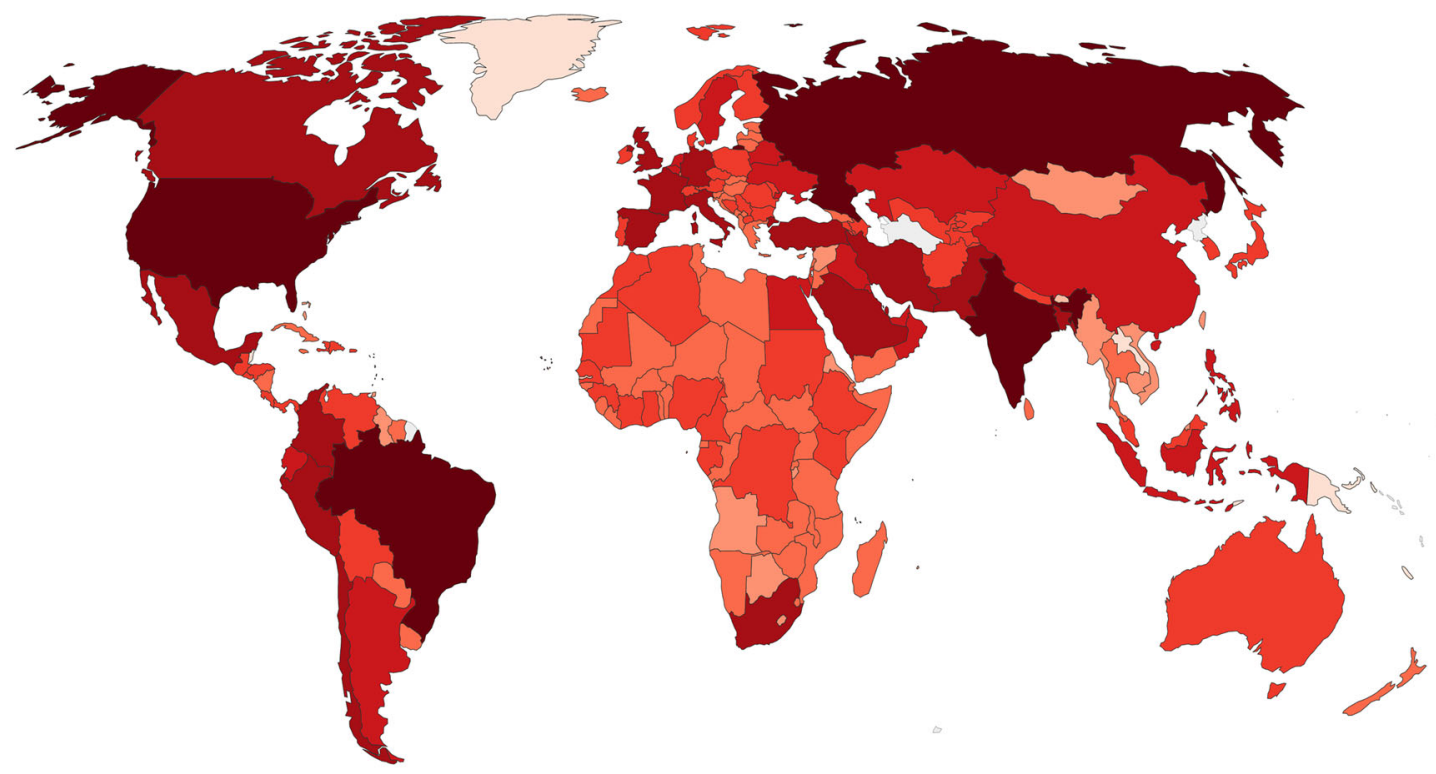

No data 0

10

50

100

5,000

50,000

$100,000 \quad 500,000>1$ million

Fig. 1 Timeline of the global COVID-19 pandemic. a The timeline spans December 31st, 2019, to July 12th, 2020. It shows the significant events related to the number of cases and deaths globally. b As of July 12th, 2020, the representative world map shows the global distribution and the incidence of reported COVID-19 cases in each country. Clusters of pneumonia that had unknown origins were first reported from Wuhan on December 31st, 2019, to the China National Health Commission. On January 13th, 2020, the WHO reported the first cases outside of China in Thailand. The virus was named SARS-CoV-2 by the WHO on February 11th, 2020, and the disease was named COVID-19. On February 14th, 2020, Africa had its first confirmed case of coronavirus after a person in Egypt tested positive for the disease. In late February and early March, multiple international reports of SARS-CoV-2 confirmed over 82,000 people had been infected and over 2800 patients had died worldwide. The WHO declared COVID-19 officially a pandemic on March 11, 2020, as the viral disease swept into at least 114 countries and killed more than 4000 people. When Italy was the epicenter of the COVID-19 pandemic, roughly
7000 newly infected coronavirus cases were registered per day in the country on March 21st, 2020. Seven days later the number climbed to $>600,000$ cases with the death toll reaching 27,000 . However, the true scale of the outbreak was thought to be significantly higher. Confirmed worldwide infections reached $1,000,000$ with a global death toll of 50,000 on April 1st, 2020. Within the next 2 weeks, the United States reported 500,000 cases registered and a death toll surpassing Italy's with 19,468 deaths. Throughout April, U.S. officials alleged that China was underreporting the total number of cases and deaths; on April 25th, 2020, there were no new cases and death reports for 10 days in a row, while the global death toll surpassed around 200,000. SARS-CoV-2 is continuing to spread across the world, with approximately 12.7 million confirmed cases in 213 countries. More than 560,000 people have died. The United States alone has more than 3.3 million confirmed cases, significantly more than the total confirmed cases reported by any other country (the next highest being Brazil with more than 1.8 million) as of July 12th 2020 
pathogenesis of SARS-CoV-2 is urgently needed for devising disease interventions and vaccine strategies (Zumla et al. 2016; Zhang et al. 2020c). Coronaviruses belong to a large family of single-stranded RNA viruses that can be isolated from different animal species; infection induces enteric and respiratory diseases within the host. The viruses are spherical or pleomorphic, with a diameter of 80-160 nm (Cui et al. 2019a; Britannica 2020). The characteristic features of coronaviruses are the club-shaped spike projections emanating from the surface of the virion, which provide them the appearance of a solar corona. Coronaviruses can cross species barriers and cause severe diseases in humans, such as MERS and SARS (Fig. 2). Prior to 2002, coronaviruses were considered exclusively as veterinary pathogens and the causative agents of the common cold in humans. During 2002-2003, the outbreak of SARS changed this ideology. As mentioned, SARS was caused by a novel coronavirus SARS-CoV (Coleman and Frieman 2014; Fehr and Perlman 2015).

\section{Classification and Molecular Structure}

The SARS-CoV-2 is a pleomorphic, enveloped, positivesense, single-stranded RNA virus with a genome size ranging from 26 to 32 kilobases (Gorbalenya et al. 2020; Lu et al. $2020 \mathrm{a})$. The size of its virion is roughly $80-120 \mathrm{~nm}$ in diameter (Cui et al. 2019a; Britannica 2020; Wrapp et al. 2020). SARS-CoV-2 shows $79.0 \%$ and $51.8 \%$ nucleotide sequence identity to SARS-CoV and MERS-CoV, respectively. It is closely related to bat-origin SARS-like coronavirus (bat-SLCoVZC45) with 87.6-89\% nucleotide identity (Ren et al. 2020). Therefore, bats are likely the natural hosts for SARSCoV-2. Pangolins are believed to be one of the intermediate hosts for species viral transfer to humans (Fig. 2). The other intermediate hosts remain undefined (Lam et al. 2020). Similar to other coronaviruses, SARS-CoV-2 binds to the angiotensin-converting enzyme 2 (ACE-2) receptor on epithelial cells (Li et al. 2005b).

SARS-CoV, MERS-CoV, and SARS-CoV-2 have four structural proteins: spike (S) protein, nucleocapsid (N) protein, membrane "matrix" (M) protein, and envelope (E) proteins; however, the assembly of these proteins into the infectious virion leads to distinct toxicity and infectivity of these coronaviruses (Rey and Lok 2018; Kang et al. 2020b; $\mathrm{Lu}$ et al. 2020a). The three-dimensional structure of the newly emerged SARS-CoV-2 virion shows that the nucleic acid and $\mathrm{N}$ proteins are found underneath a lipid bilayer (Walls et al. 2020). Hence, SARS-CoV-2 is known as an enveloped virus, which utilizes lipids from the host cell when it buds off to form a new virion (Schoeman and Fielding 2019). SARS-CoV-2 viral particles appear as clean amorphic structures with defined transmembrane proteins decorating a phospholipid bilayer outer membrane (Fig. 3). Within the envelope, SARS-CoV-2 viral particles carry one strand of a 30 kilobase positive-sense RNA genome which codes for 4 structural proteins. $\mathrm{N}$ proteins protect the viral genome from outside host cells. Upon cell entry, the $\mathrm{N}$ protein uncoats, and the viral genome is directly translated by host cell ribosomes. Viruses do not make their own lipids; instead, they repurpose host lipids for their replication and morphogenesis. The other three structural proteins $(\mathrm{E}, \mathrm{M}, \mathrm{S})$ form the viral envelope that are embedded into the repurposed cellular lipid bilayer before budding off the infected cell (Khailany et al. 2020; Zhang et al. 2020c). Under electron microscopy, surface proteins, particularly S proteins (Fig. 3) give the appearance of a crown (Latin: corōna) surrounding the viral particle and give the virus its common name: coronavirus ( $\mathrm{Li}$ et al. 2005a; Zhang et al. 2020c). The most abundant protein on the outside of the viral membrane is a glycoprotein $\mathrm{M}$ protein. $\mathrm{M}$ proteins act by binding the nucleic acid genome to the inner surface of the host cell membrane. The C-terminal domain of transmembrane proteins contacts the $\mathrm{N}$ protein, which is important for the morphogenesis phase of the viral life cycle (Siu et al. 2008; Rey and Lok 2018).

A cryo-electron microscopy structure of SARS-CoV-2 S protein has been elucidated. Studies overlaid SARS-CoV-2 and SARS-CoV S protein structures and identified conserved amino acids (Baig et al. 2020; Srinivasan et al. 2020; Wrapp et al. 2020). The $\mathrm{S}$ protein is trimeric with two domains ( $\mathrm{Li}$ 2016; Srinivasan et al. 2020). The upper lobular domain contains an ACE-2 receptor-binding feature that engages the host cell to initiate cell entry. The receptor-binding domain is the most variable part of the coronavirus genome, a common trait of viruses in general. High sequence variability is a direct result of the intense evolutionary pressure that the host immune systems exert on the virus. The lower domain of the $\mathrm{S}$ protein contains the machinery required for the virus to fuse with the host cell membrane. The fusion domain tends to be conserved among coronaviruses and contains a hydrophobic fusion peptide, which brings together the two lipid bilayers close enough for fusion to occur ( $\mathrm{Li}$ et al. 2005a; Yan et al. 2020; Zhang et al. 2020c).

\section{Viral Life Cycle}

The replication cycle of the SARS-CoV-2 virus infection into the host cell can be divided into several key steps: (a) attachment and cell entry, (b) transcription of viral replicase, (c) genomic transcription and replication, (d) translation of structural proteins, and (e) virion assembly and release. In the following section, we briefly review each step (Fig. 3) (Fehr and Perlman 2015; Lu et al. 2020a).

Attachment and cell entry. The spike protein (S) of SARS$\mathrm{CoV}-2$, structurally similar to that of SARS-CoV, is the major 


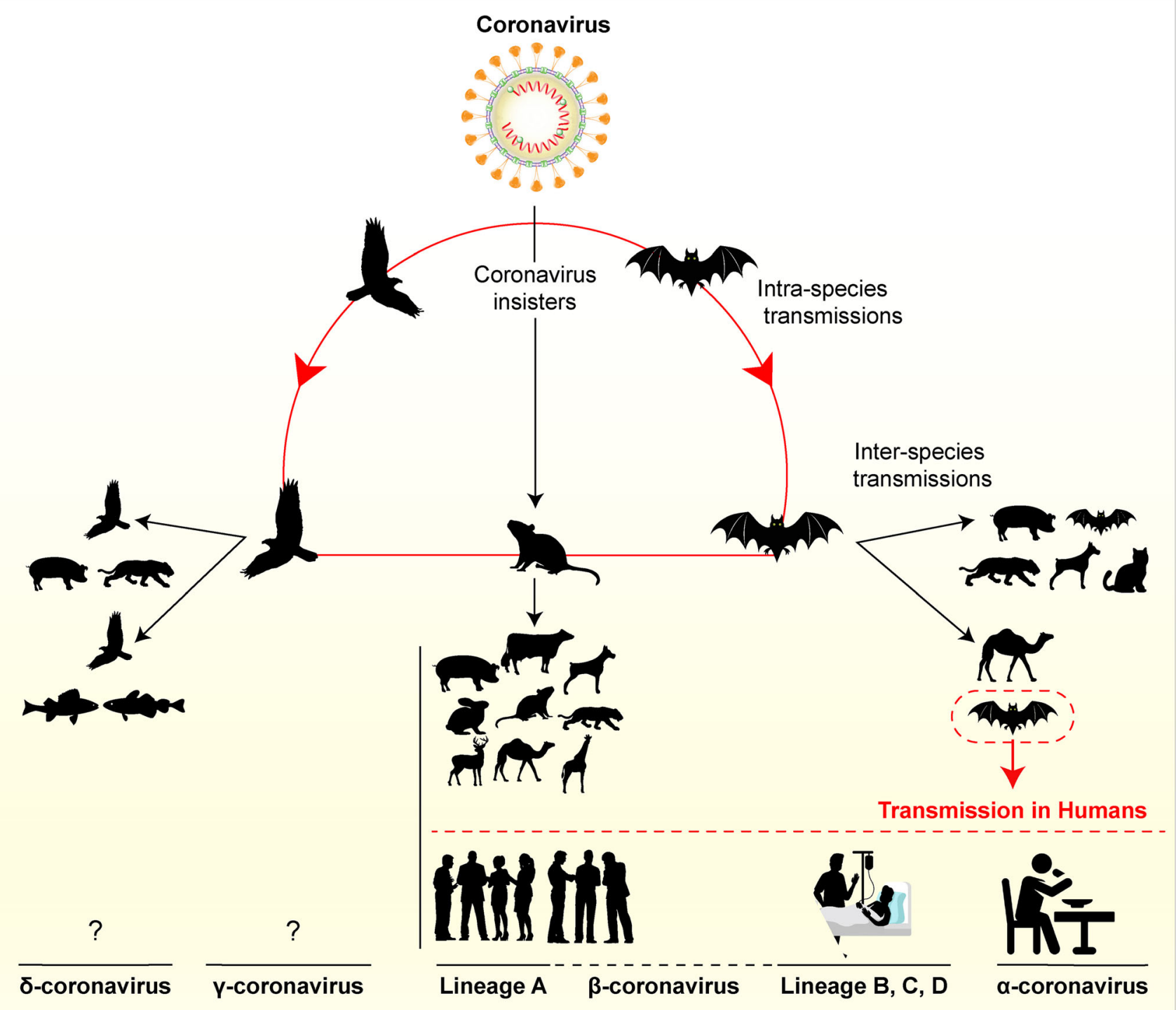

Fig. 2 SARS-CoV-2 transmission. Intra-species and inter-species dissemination of coronavirus. Initial hosts include bats, birds, and rats. COVID-19 is a member of the B lineage in the beta-coronavirus family, of which SARS-CoV-1 also descended. The WHO has characterized COVID-19 as a pandemic. As the virus spreads, so too does misinformation about its origins. The World Health Organization has categorized COVID-19 as a pandemic considering its spread far and wide. The spread of zoonotic disease from species that it evolved with to a new host is exacerbated by wildlife trafficking, habitat destruction, and climate change. These threats bring humans and animals closer together. Coronavirus is just an example of a string of pathogens that have come from wildlife trafficking, including SARS, Ebola, Bird Flu, and many more. In the case of wildlife trafficking and poaching, animals are hunted, trapped, and taken to markets to be sold for traditional medicine, food,

viral determinant for host tropism by dictating cell entry through binding cellular receptors and initiating fusion, and hence infection (Hoffmann et al. 2020; Wrapp et al. 2020). Coronavirus $\mathrm{S}$ protein binds to the cellular transmembrane protein, ACE-2 receptor, which promotes priming of S protein by host protease and is responsible for viral entry (Hoffmann and the pet trade. The wild animals can harbor diseases that can make other animals, including humans, sick. Wildlife trade markets facilitate viral transmission. They allow multiple species to be in proximity that otherwise would not come into prolonged contact with one another, which could be a factor for virulent strains of pathogens spreading to humans. Additionally, human capture of wildlife and incursion into natural wildlife habitats allow viruses to jump the species barrier. Addressing the legal trade and illegal trafficking of wild animals will help to stop the spread of zoonotic pathogens. Closing wildlife markets and controlling wildlife poaching would forestall the spread of zoonotic pathogens while also addressing a significant driver of species annihilation. China has recently shut all of its wild-life animal markets and this step has been applauded globally

et al. 2020; Zhang et al. 2020d). The S protein of SARS-CoV2 has a strong binding affinity for the ACE- 2 receptor. The binding of S proteins to ACE-2 leads to a proteolytic cleavage event that exposes the fusion peptide. A cellular protein called transmembrane protease serine 2 (TMPRSS-2) carries out this cleavage (Yan et al. 2020; Zhang et al. 2020c). 


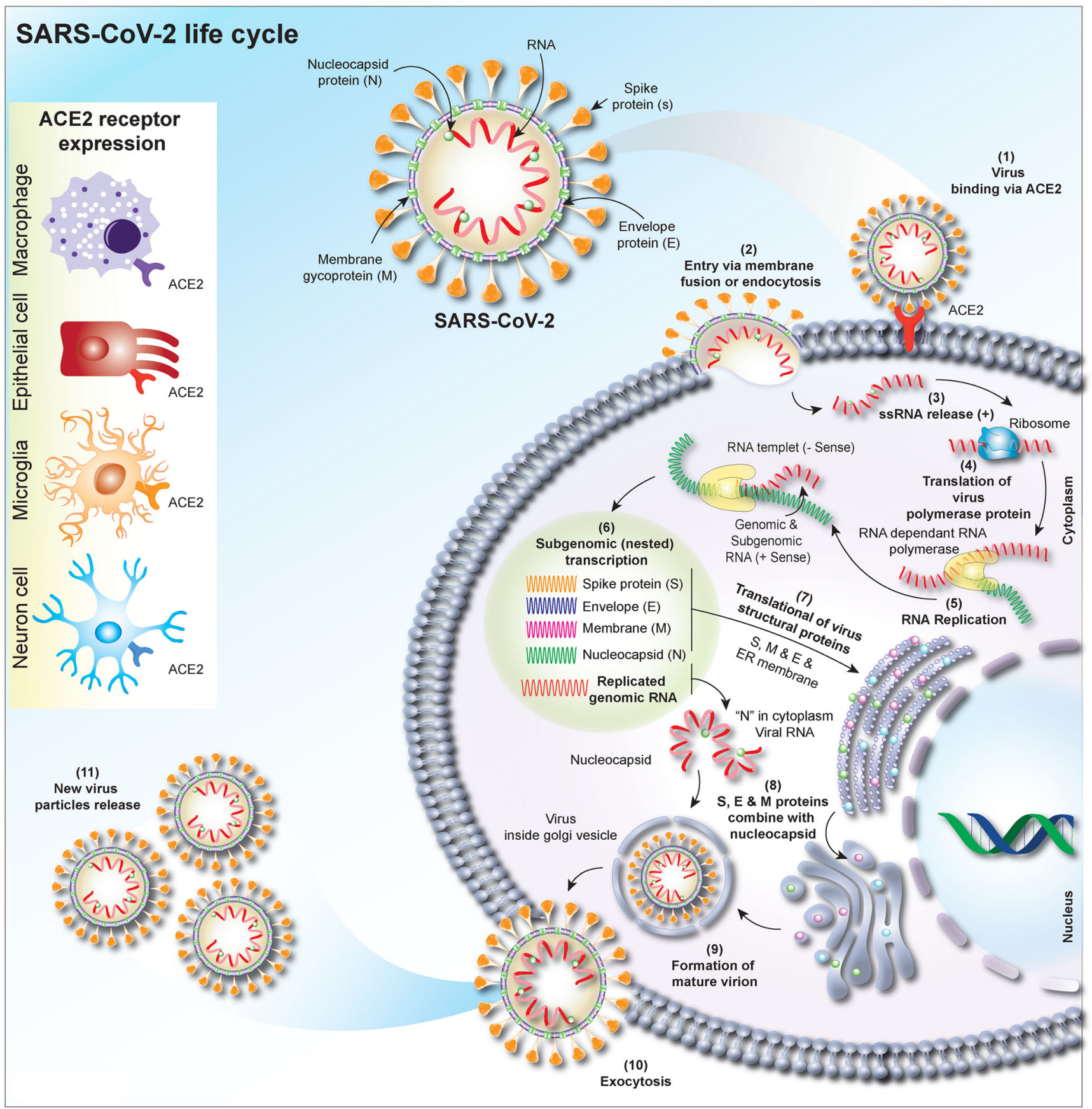

Fig. 3 SARS-CoV-2 life cycle in virus susceptible host cells. ACE-2 binds to the receptor-binding domain (RBD) of spike proteins (S) (1), allowing for fusion with the host cell membrane (2). Positive sense single-stranded RNA is released (3), partially translated into SARSCoV-2 polymerase protein (4-5), and transcribed (6). The resultant

The SARS-CoV-2 spike protein represents a classic class-I fusion protein, characterized by the presence of a trimer of $\alpha$ helical coiled-coils in the protein's active site. Other related viruses utilize fusion proteins of this type; the bestcharacterized is the hemagglutinin protein of influenza. Other notable class-I fusion proteins include the Ebola virus fusion protein and the HIV fusion protein (Bosch et al. 2003; subgenomic RNA translational S, M, and E proteins are taken to the host cell ER membrane (7) and later combined with nucleocapsid protein $(\mathrm{N})$ (8). Post Golgi processing, all elements are incorporated into a mature virion (9) and traffic to the cell membrane for exocytosis (10) of newly budded SARS-CoV-2 particles (11)

Li 2016). Class-I fusion proteins protect the fusion domain by keeping it tucked away and inactive until the virus encounters an appropriate host cell where it is then proteolytically activated to form a hairpin structure. This structure, referred to as the fusion peptide, is embedded into the target cell membrane (Li 2016; Rey and Lok 2018). The fusion peptide is usually a stretch of hydrophobic amino acids and can be inserted into a 
lipid membrane. This hairpin-like structure then begins to fold back, forming a 6-helix bundle and pulls the cellular and viral membranes together to promote fusion. This leads to cellular entry and delivery of the nucleocapsid payload to the cytosol. Cellular entry may occur directly at the plasma membrane upon endocytosis or through other processes that have not yet been fully resolved (Bosch et al. 2003; Fehr and Perlman 2015; Rey and Lok 2018). Usually, class-I fusion proteins adopt trimeric hairpin conformations post-fusion (Bosch et al. 2003; Rey and Lok 2018).

Despite structural similarities, studies have identified interesting features that distinguish SARS-CoV-2 $\mathrm{S}$ protein from the original SARS-CoV spike protein. The first difference arises from the composition of six critical amino acids within the ACE-2 binding domain. Interestingly, five of these six residues are different for SARS-CoV-2 than for SARS-CoV1. Nonetheless, SARS-CoV-2 is still able to interact much more efficiently with the ACE-2 receptor (Wrapp et al. 2020; Yan et al. 2020). The second notable difference is that SARS-CoV-2 seems to have acquired a polybasic cleavage site in the region critical for fusion peptide activation. This polybasic cleavage site is notable because it is predicted to enable cleavage by different cellular proteases than those utilized by SARS-CoV (Hoffmann et al. 2020; Yan et al. 2020).

The key region of SARS-CoV-2 that interacts with the human ACE-2 receptor, S1 c-terminal domain, was identified recently by biochemical and crystallographic analysis (Cao et al. 2020; Shang et al. 2020; Yan et al. 2020). These studies demonstrated the strong binding affinity of SARS-CoV-2 relative to SARS-CoV to the ACE-2 receptor. Monoclonal antibodies, as well as murine polyclonal antisera against SARS$\mathrm{S} 1 / \mathrm{RBD}$ (receptor binding domain), were unable to bind to the SARS-CoV-2 $\mathrm{S}$ protein, elucidating differences in antigenicity between SARS-CoV and SARS-CoV-2. These results help rule out the use of previously developed SARS-RBD-based vaccine candidates for SARS-CoV-2 prophylaxis (Baig et al. 2020; Wrapp et al. 2020). Thus, ACE-2 receptors play an essential role in viral S protein binding and internalization. Host cell proteases play a crucial role in triggering conformational shifts in S proteins, a process known as priming. A critical study revealed that the SARS-CoV-2 host cell entry via ACE-2 could be blocked by an inhibitor of the cellular serine protease TMPRSS2, which is employed by SARSCoV-2 for S protein priming (Hoffmann et al. 2020). Thus, inhibitors against the ACE-2 and protease could be used as potential therapeutic agents to intervene in rapid SARS-CoV2 transmission (Hoffmann et al. 2020; Wang et al. 2020b). Other receptors like C-type lectin CD209L (L-SIGN), and DC-SIGN used by SARS-CoV are under active investigation as possible alternatives for SARS-CoV-2 binding, entry, and cell tropism (Li et al. 2005a; Masters 2006; de Wit et al. 2016). As is the case with HIV-1, SARS-CoV-2 may alter its tropism towards different receptors with disease progression (Walls et al. 2020), though further investigation is needed to elucidate such hypotheses.

Transcription of Viral Replicase Upon successful entry and uncoating of the virus, the genomic RNA (sgRNA) serves as a transcript and allows the cap-dependent translation of ORF1a producing polyprotein pp1a. Next, a slippery sequence and an RNA pseudoknot towards the end of ORF1a leads to $25-30 \%$ of the ribosomes to undergo frameshifting, hence continuing translation on ORF1b and producing a longer polyprotein pp1ab (Masters 2006). The autoproteolytic cleavage of ppla and pp1ab generates 15-16 nonstructural proteins (nsps) which possess specific functions. The RNAdependent RNA polymerase (RdRP) activity is encoded by nsp12 (Xu et al. 2003; Gao et al. 2020), whereas the nsp3 and nsp5 respectively encodes papain-like protease (PLPro) and the main protease (Mpro) (Ziebuhr et al. 2000). Then, nsp3, 4, and 6 induce the rearrangement of the cellular membrane to form double-membrane vesicles (DMVs) (Angelini et al. 2013; Maier et al. 2013), where the coronavirus replication transcription complex (RTC) is assembled and anchored. Programmed ribosomal frameshifting (PRF) is possibly regulated by viral and host factors apart from the RNA secondary structures. A host RNA binding protein called annexin A2 (ANXA2) was shown to bind the pseudoknot structure within the infectious bronchitis virus (IBV) genome (Li 2016). In terms of DMV formation and RTC assembly, several host factors of the early secretory pathway seem to be involved. Golgi-specific brefeldin A-resistance guanine nucleotide exchange factorl (GBF1) and its effector ADP ribosylation factor 1 (ARF1) are both essential for normal DMV formation and efficient RNA replication of mouse hepatitis virus (MHV), a prototypic beta coronavirus which primarily infects mice (Verheije et al. 2008). Various drug targets from these transcription and translation steps are under investigation using in silico modeling for susceptible binding pockets in RNA-dependent RNA polymerase (RdRP) and proteases where current antivirals and inhibitors could bind (Wu et al. 2020a). Computational modeling may accelerate a path towards clinical trials by screening existing therapeutics that can be repurposed to combat SARS-CoV-2 infection (Wu et al. 2020a).

Genomic Transcription and Replication The RNA genome of SARS-CoV-2 works as a template for replicase to synthesize full-length antisense genome; this serves as a template for the synthesis of new genomic RNA (Ziebuhr 2005; Masters 2006; Wrapp et al. 2020). The polymerase switches templates during discontinuous transcription at specific sites of the genome, resulting in a $5^{\prime}$-nested set of negative sense subgenomic RNA molecules (sgRNAs), which are used for the synthesis of a 3'nested set of positive-sense sgRNAs (Masters 2006; Wrapp et al. 2020). Although, viral replicase primarily mediates 
genomic transcription, the roles of various host factors and nonstructural viral proteins are still being brought to light.

The nucleopcapsid $(\mathrm{N})$ protein is known to serve as an RNA chaperone and aids in controlling RNA template reading (Zuniga et al. 2007; Zuniga et al. 2010). The N proteins of SARS-CoV coronavirus strains and mouse hepatitis virus strain JMH (MHV-JHM) are phosphorylated by glycogen synthase kinase 3 (GSK3). GSK mediated phosphorylation of $\mathrm{N}$ protein facilitates the synthesis of genomic RNA and longer sgRNAs (Wu et al. 2014). Treatment of SARS-CoVinfected Vero E6 cells using a GSK3 inhibitor resulted in inhibition of viral replication (Qinfen et al. 2004; Wu et al. 2009). An RNA-binding protein, heterogeneous nuclear ribonucleoprotein A1 (hnRNPA1), also could bind tightly to SARS-CoV N protein and regulate viral RNA synthesis (Luo et al. 2005). In addition, host RNA-binding proteins play a crucial role by directly binding to untranslated regions (UTRs) of the coronavirus genome and regulate replication and transcription. Among these, zinc finger CCHC-type and RNA-binding motif 1 (ZCRB1) binding to the 5'-UTR of IBV (Tan et al. 2012), mitochondrial aconitase binding to the 3'UTR of MHV (Nanda and Leibowitz 2001), and poly(A)binding protein (PABP) binding to the poly(A) tail of bovine coronavirus (Spagnolo and Hogue 2000) are noteworthy. Thus, due to the similarity of the SARS-CoV-2 genome with SARS-CoV-1, these mechanisms are mostly predicted to be utilized and need further investigation and experiments to prove their precise occurrence or any diversion in mechanisms. A high-resolution map of SARS-CoV-2 transcriptome and epitranscriptome revealed that its transcription process is complex involving numerous discontinuous transcription events (Kim et al. 2020). Furthermore, the presence of several RNAs were discovered, which encode unknown ORFs, in addition to 10 known canonical RNAs. This extensive study also found around 41 potential RNA modification sites with an AAGAA motif (Kim et al. 2020). Future studies will provide the exact use of these divergent transcripts in viral transcription and replication and their role in the infection mechanism of this highly virulent pathogen.

Translation and Structural Proteins Coronavirus sgRNAs are functionally monocistronic, and only the 5 '- ORF is translated in a cap-dependent manner (Masters 2006). However, some sgRNAs employ other mechanisms, including ribosome leaky scanning and ribosome internal entry, leading to the translation of additional ORFs (Liu and Inglis 1991). Transmembrane structural proteins ( $\mathrm{S}, \mathrm{HE}, \mathrm{M}$, and $\mathrm{E}$ ) and some membraneassociated accessory proteins are translated in the endoplasmic reticulum (ER), but the $\mathrm{N}$ protein is translated by cytosolic ribosomes (Masters 2006). Ribosome profiling studies have identified ribosome pause sites and revealed several short ORFs upstream of known viral protein-encoding regions (Irigoyen et al. 2016).
Further, coronavirus structural proteins are subjected to post-translational modifications and deemed fully functional (Fung and Liu 2018). Both S and M proteins are known to be modified by glycosylation (Zheng et al. 2018). Beyond the role of N-linked glycosylation of SARS-CoV S proteins in receptor binding (Sui et al. 2004), glycosylated S proteins have been implicated in lectin-mediated virion anchoring (Han et al. 2007) and possibly constituting some neutralizing epitopes (Song et al. 2004). O-linked glycosylation of M proteins modulate MHV to induce type I interferon and replication in mice (de Haan et al. 2003). Folding and maturation of viral transmembrane proteins (S) also occurs in, and are modulated by, ER protein chaperones such as calnexin (Fukushi et al. 2012). Processing of polyproteins translated from the viral RNA are essential and carried out by the main protease $\left(\mathrm{M}^{\text {pro }}\right.$, also called $\left.3 \mathrm{CL}^{\text {pro }}\right)$. Hence, this could be an attractive drug target for SARS-CoV-2 as harvested in other coronaviruses. A recent study reported the x-ray structures of the unliganded SARS-CoV-2 $\mathrm{M}^{\text {pro }}$ and its complex with an $\alpha$-ketoamide inhibitor (Zhang et al. 2020c). Based on the unliganded structure, a lead compound was developed as a potent inhibitor of the SARS-CoV-2. Further, the pharmacokinetic characterization of the inhibitor revealed its lung tropism and suitability for administration by inhalation (Zhang et al. 2020c).

Assembly and Virion Release Based on the knowledge acquired from other coronaviruses, we know assembly of SARS-CoV-2 virion particles takes place in the ER-Golgi intermediate compartment (ERGIC) and is mediated by the membrane (M) protein (Klumperman et al. 1994; Kono et al. 2008). M proteins direct protein-protein interaction, with the scaffold leading to virion morphogenesis, M-S, and M-N interactions, and facilitating the recruitment of structural components to the assembly site (Nakauchi et al. 2008; Siu et al. 2008). E protein contributes in the viral particle assembly by interacting with M proteins (Lim and Liu 2001). Coronavirus particles budded into the ERGIC are transported using smooth-wall vesicles, resulting in trafficking via the secretory pathway, and finally, released by exocytosis. Several host factors are implicated in the assembly and the release of coronavirus, the intricate interactions between the cytoskeleton and structural proteins play a pivotal role. Tubulins and the cytosolic domain of S protein interactions between HCoV-229E, HCoV-NL63, and transmissible gastroenteritis virus (TGEV) lead to successful assembly and release of viral particles (Reggiori et al. 2010). Also, IBV M protein, $\beta$-actin, TGEV $\mathrm{N}$ protein, vimentin, TGEV S protein, and filamin A (an actinbinding protein) interactions, all facilitate coronavirus particle assembly and release (Wang et al. 2009; Zhang et al. 2015). These steps of virus maturation and release could also be an attractive target for drug-repurposing using different antivirals and a combination of antivirals (Zhou et al. 2020d). Future 
studies will help in determining the exact mechanisms of SARS-CoV-2 budding and identification of key targets for intervention of disease transmission and progression.

\section{Cell and Tissue Tropism and Disease Pathobiology}

In severe COVID-19 infection, the dysregulated immune system responds by secreting cytokines in an uncontrolled manner leading to marked increases in cytokine release, or a "cytokine storm" syndrome (Moore and June 2020; Zhang et al. 2020b). The neutrophil-to-lymphocyte ratio (NLR) is the leading indicator of cytokine storms (hypercytokinaemia), with increased NLR in the blood due to the elevated cytokine levels. SARS-CoV-2 can infect monocytes, macrophages, dendritic cells, and lymphocytes, which together play an indispensable role in the development of cytokine storm (Grifoni et al. 2020; Park 2020; Yuki et al. 2020). Cytokines are small proteins (e.g., IL-6, IL8, IL-10, TNF- $\alpha$ ) released to send signals for recruiting immune cells to fight off the virus (Moore and June 2020). This is an essential response for selfdefense against any infection. In COVID-19 cases, excessive amounts of cytokines are released which dramatically increase leukocyte recruitment to multiple body organs, most notably the lung cells, leading to the acute respiratory distress syndrome (ARDS) (Zhang et al. 2020a) (Fig. 4). Such cytokine storms are not a new phenomenon; they occur in a variety of viral illnesses, including SARS, MERS, influenza, and in primary or secondary hemophagocytic lymphohistiocytosis.

One of the main problems of the COVID-19 pandemic is that disease symptoms are diverse and may have varied manifestations among the patients. Some symptoms are incredibly severe, while others are so mild that patients appear asymptomatic (Guo et al. 2020b). In severe cases, a typical pattern of disease progression occurs; however, patients with mild disease may show signs of recovery after the first week, but some may have persistent symptoms or may deteriorate again rapidly thereafter (Song et al. 2020). The most common COVID19 symptoms tend to appear in about 2 to 14 days after virus exposure which include fever, muscle pain, headache, cough, sore throat, and loss of taste or smell (CDC 2020b). In severe cases, due to overwhelming lung infection, emergency signs arise including difficulty in breathing due to the pneumonia (Chen et al. 2020b; Huang et al. 2020). The most characteristic clinical course of severe COVID-19 patients is the development of ARDS. This life-threatening lung condition prevents sufficient oxygen from crossing the alveoli into the blood. Therefore, to increase oxygen to the lungs, patients are put on mechanical ventilators. Despite such intensive efforts, approximately $40 \%$ of ARDS patients do not survive. Pathophysiologically, the lungs suffer from a cytokine storm that damages the pulmonary tissue, leading to hypoxemia, along with end stage multiorgan failure (Sun et al. 2020). The clinical manifestations of SARS-CoV-2 infection in major body organs are summarized in Table 1 .

\section{Infection and Dissemination}

Research on how the infection is transmitted from one person to another remains incomplete. The major route of SARS$\mathrm{CoV}-2$ transmission is through the infected fluid droplets secreted by the respiratory system of infected individuals. The virus spreads through respiratory droplets from infected individuals while sneezing, coughing or talking without covering the mouth and the nose. The expelled droplets may also linger in the air and infect individuals that come into contact with them in an enclosed space (Gandhi et al. 2020; Meselson 2020; Morawska and Cao 2020). COVID-19 transmission also occurs via the following ways ( $\mathrm{Li}$ et al. 2020a): (a) Direct bodily contact with infected persons. (b) Contacting contaminated surfaces or objects, as scientists have reported, that coronavirus remains stable on plastic and stainless steel up to $72 \mathrm{~h}$, more than $4 \mathrm{~h}$ on copper and up to $24 \mathrm{~h}$ on cartons (Rubens et al. 2020; van Doremalen et al. 2020). However, it remains unclear whether the presence of the virus on the surface indicates viable infectivity. (c) Touching the mouth, eyes, or nose with unwashed and contaminated hands (d) Transferring the virus by touching or smelling feces, although this route of transmission is considered very rare. (e) Fecal microbiota (FMT) isolated from SARS-CoV-2 positive people may also be a source for COVID-19 transmission according to recent FDA guidelines. Therefore, any FMT donated after December 1st, 2019, are tracked and tested for COVID-19 (Ransom et al. 2020).

\section{End Organ Diseases}

Infection and viral dissemination are associated with endorgan diseases. As its name suggest, SARS-CoV-2 is known to affect patients' lungs, often inducing ARDS (Ranieri et al. 2012; Chu et al. 2020). However, clinicians and researchers around the world have reported the devastating effects of COVID-19 on other major organs, including blood vessels, brain, gastrointestinal (GI) tract, kidney, heart, and liver (Fig. 5) (Chu et al. 2020; Lescure et al. 2020; Wang et al. 2020a). This understanding has broadened the diagnostic criteria and treatments for COVID-19 patients.

Central Nervous System (CNS) Previous studies have shown that human coronaviruses enter the brain from systemic circulation or through synaptic connections and retrograde neuronal dissemination (Netland et al. 2008; Li et al. 2020b). The latter route was observed in mice, in whom SARS-CoV entered via the nose close to the olfactory epithelium. Transneuronal spreading to the connected brain areas ensued (Netland et al. 


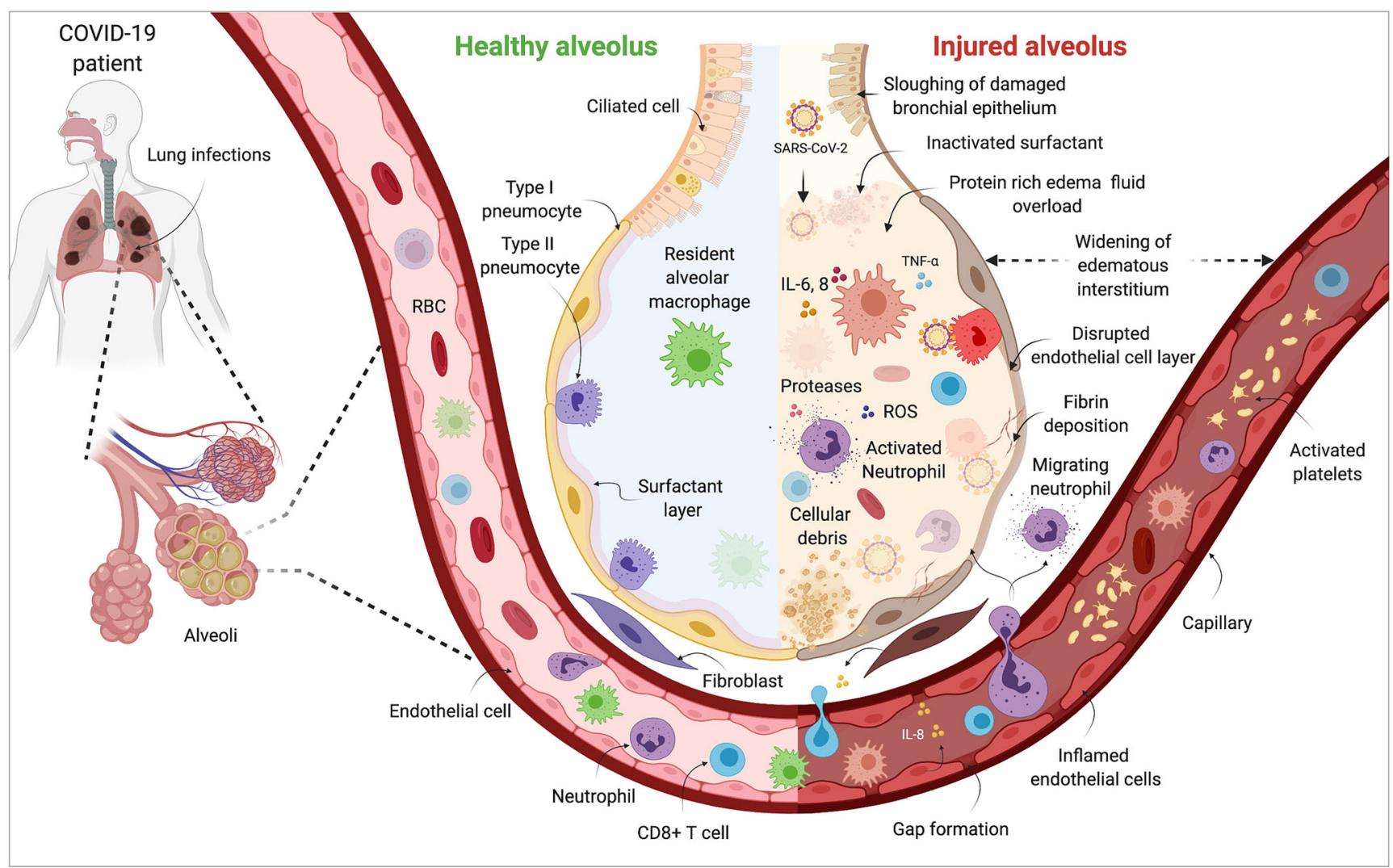

Fig. 4 ARDS in severe SARS-CoV-2 infections. Development of SARS-CoV-2 infection in the lower lung results in fluid collection within the bronchioles, which disrupts protective surfactant coatings typically released by type II pneumocytes. This leads to alveolar instability and the sloughing of endothelial cells. Additionally, ARDS causes a

2008). These findings were verified in patients who showed the presence of SARS-CoV virion particles in the cerebrospinal fluid (CSF) and brain autopsy samples (Hung et al. 2003; Gu et al. 2005). In another study of hospitalized children with suspected acute encephalitis, $11 \%$ had unspecified coronavirus infection (Hon et al. 2003). In other reports, among MERS$\mathrm{CoV}$ infected patients, altered mental status was reported in $26 \%$ of patients (Saad et al. 2014). Therefore, with COVID19, neurological manifestations are expected. To this end, emerging case reports and series have documented various neurological disorders with SARS-CoV-2 infection (Helms et al. 2020; Mao et al. 2020a; Moriguchi et al. 2020; Toscano et al. 2020; Zhou et al. 2020a). Although less prevalent than the pulmonary illness, neurological involvements were reported in $36.4 \%-67 \%$ of COVID-19 patients (Helms et al. 2020; Mao et al. 2020a). This variable prevalence of neurological disorders may partly be due to the limited data available, difficulty in recognizing the neurological deficits when the severely ill patients are sedated during intubation, or had encephalopathy. Conversely, the mild or moderate symptoms of neurological deficits may not be recognized if neurological specialists were hyperactive immune response, localizing neutrophils, and increasing cytokine release, which leads to the accumulation of reactive oxygen species, cell debris, and proteases. Edema results from protein accumulation in interstitial space and vasoconstriction via platelet activation, which further decreases oxygen exchange capacity

not involved in these patients' management (Helms et al. 2020; Mao et al. 2020a).

Multiple reports have confirmed the neurotropism of SARS-CoV-2. Autopsy samples of COVID-19 patients showed that their brain tissue was hyperemic, edematous, and that neuronal demise was accompanied with detectable viral particles (Huang et al. 2020; Mao et al. 2020a). The SARS-CoV-2 present in the systemic circulation may enter the cerebral circulation where the sluggish movement of the blood, due to the hypercoagulable state within the microvasculature, may facilitate SARS-CoV-2 spike protein interactions with the capillary endothelium. The capillary endothelium has ACE-2 receptors that allow virion particles to pass through the meningeal endothelial lining to enter the brain. In the brain, virion particles then interact with ACE-2 receptor expressing neuroglia cells to initiate the cycle of viral dissemination that cause neuronal damage (Baig et al. 2020). Like SARS-CoV, SARS-CoV-2 can enter the brain through the olfactory pathway which is evidenced by the fact that some COVID-19 patients present clinically with smell impairments (Eliezer et al. 2020). 
Table 1 Clinical manifestation of SARS-CoV-2 Infection

\begin{tabular}{|c|c|c|c|c|}
\hline $\begin{array}{l}\text { Organ system } \\
\text { involved }\end{array}$ & $\begin{array}{l}\text { Disease Onset } \\
\text { (Mild disease) }\end{array}$ & Moderate disease & Severe Disease & Diagnostic Signs \\
\hline $\begin{array}{l}\text { Lung/Respiratory- } \\
\text { Pulmonary }\end{array}$ & $\begin{array}{l}\text { - Cough } \\
\text { - Sore throat } \\
\text { - Rhinorrhea, } \\
\text { Sneezing } \\
\text { - Dry Cough }\end{array}$ & $\begin{array}{l}\text { - Pneumonia } \\
\text { - Dyspnea } \\
\text { - Moderate hypoxemia }\end{array}$ & $\begin{array}{l}\text { - Severe hypoxemia } \\
\text { - Acute respiratory distress } \\
\text { syndrome (ARDS) } \\
\text { - Respiratory failure and death } \\
\quad \text { (if untreated) }\end{array}$ & $\begin{array}{l}\text { - Decreased \% pO2 } \\
\text { - Chest X-rays show ground } \\
\text { glass opacities }\end{array}$ \\
\hline Brain/Neurological & $\begin{array}{l}\text { - Hyposmia- } \\
\text { Anosmia } \\
\text { - Hypogeusia- } \\
\text { Ageusia } \\
\text { - Visual Disturbance } \\
\text { - Fatigue, } \\
\quad \text { Somnolence }\end{array}$ & $\begin{array}{l}\text { - Headaches } \\
\text { - Nausea and vomiting } \\
\text { - Dizziness } \\
\text { - Myalgia } \\
\text { - Ataxia } \\
\text { - Encephalopathy }\end{array}$ & $\begin{array}{l}\text { - Cerebrovascular disease } \\
\text { (large vessel strokes) } \\
\text { - Seizures } \\
\text { - Meningoencephalitis } \\
\text { - Neuropathy } \\
\text { - Guillain Barre Syndrome } \\
\text { - Neurogenic ARDS } \\
\text { - Coma }\end{array}$ & $\begin{array}{l}\text { - Elevated creatine kinase with } \\
\text { myalgia } \\
\text { - Brain MRI show hyperintensities } \\
\text { in regions with infarction } \\
\text { or encephalitis } \\
\text { - SARS-CoV-2 detection in } \\
\text { cerebrospinal fluid or brain } \\
\text { tissues in some patients }\end{array}$ \\
\hline Gastrointestinal & $\begin{array}{l}\text { - Nausea, Vomiting } \\
\text { - Diarrhea } \\
\text { - Heartburn }\end{array}$ & $\begin{array}{l}\text { - Loss of appetite } \\
\text { - Abdominal pain and } \\
\text { bloating }\end{array}$ & $\begin{array}{l}\text { - Gastrointestinal bleeding } \\
\text { - GI viral dissemination }\end{array}$ & $\begin{array}{l}\text { - Elevated liver enzymes and } \\
\text { bilirubins } \\
\text { - SARS-CoV-2 detection in stool } \\
\text { samples }\end{array}$ \\
\hline Heart/Cardiac & $\begin{array}{l}\text { - Chest pain } \\
\text { - Arrhythmia, sinus } \\
\text { tachycardia }\end{array}$ & $\begin{array}{l}\text { - Cardiac inflammation, } \\
\text { immunocytic infiltration }\end{array}$ & $\begin{array}{l}\text { - Cardiomayopathy } \\
\text { - Acute heart failure }\end{array}$ & $\begin{array}{l}\text { - Elevated cardiac enzymes } \\
\text { - Abnormal EKG (Prolonged QTc } \\
\text { intervals, elevated ST) } \\
\text { - Cardiac-specific troponin and } \\
\text { brain natriuretic peptide }\end{array}$ \\
\hline Kidney/Renal & $\begin{array}{l}\text { - Proteinuria } \\
\text { - Hematuria }\end{array}$ & - Acute renal injury & - Renal failure & $\begin{array}{l}\text { Tubular necrosis and SARS- } \\
\text { CoV-2 detection in kidney }\end{array}$ \\
\hline $\begin{array}{l}\text { Blood vessels/ } \\
\text { Vascular }\end{array}$ & - Blood coagulation & $\begin{array}{l}\text { - Arterial or venous } \\
\text { thromboembolism } \\
\text { - Cytokine storms }\end{array}$ & $\begin{array}{l}\text { - Pulmonary embolism } \\
\text { - Large vessel occlusions } \\
\text { - Disseminated intravascular } \\
\quad \text { coagulation }\end{array}$ & $\begin{array}{l}\text { - Elevated D-dimer, } \\
\text { - interleukin-6, other cytokines, } \\
\text { ferritin, and lactate dehydrogenase } \\
\text { - Prolonged PT/PTT }\end{array}$ \\
\hline Mental/Psychiatric & $\begin{array}{l}\text { - Depressed mood } \\
\text { - Anxiety } \\
\text { - Insomnia } \\
\text { - Anger } \\
\text { - Fear }\end{array}$ & $\begin{array}{l}\text { - Depression } \\
\text { - Post-traumatic stress } \\
\quad \text { disorder }\end{array}$ & $\begin{array}{l}\text { Exacerbation of neurological or } \\
\text { psychiatric disorders } \\
\text { (e.g., Alzheimer's or Addiction) }\end{array}$ & $\begin{array}{l}\text { Elevated plasma calcium and } \\
\text { phosphorus (indicative of stress) }\end{array}$ \\
\hline
\end{tabular}

Major neurological manifestation of COVID-19 ranges from cognitive to cerebrovascular symptoms. In a recent series of 214 hospitalized patients with COVID-19 from Wuhan, China, 78 patients $(36.4 \%)$ had neurological manifestations, including dizziness, headaches, taste, and smell impairments, as well as acute cerebrovascular diseases, impaired consciousness, and skeletal muscle injury (Mao et al. 2020a). From a recent meta-analysis of studies published between January 1st and April 10th, 2020, occurrence of more severe psychiatric impairments including depression (29\%), anxiety (34\%) and post-traumatic stress disorder (34\%) was observed in COVID19 patients along with mild symptoms (Rogers et al. 2020a). Several other reports also documented CNS manifestations including headache, dizziness, confusion, ataxia, and seizures in subsets of hospitalized COVID-19 patients (Chen et al. 2020b; Huang et al. 2020; Wang et al. 2020a; Yang et al. 2020). Importantly, some of the neurological disorders, including a case of Guillain-Barre Syndrome (GBS) (Zhao et al. 2020), another case of meningoencephalitis (Duong et al. 2020), and acute ischemic large vessel or hemorrhagic strokes in young or middle-aged individuals (Al Saiegh et al. 2020; Oxley et al. 2020), all reported as presenting symptoms for SARS-CoV-2 infection. These patients did not show the typical fever and respiratory symptoms until many days after they were admitted for their neurological problems; hence the diagnosis for COVID-19 may easily be missed in such patients. Therefore, clinicians should have a high index of suspicion for SARS-CoV-2 infection in anyone presenting with new onset neurological disorders, and perform the necessary diagnostic tests. Distinct from infection with SARS-CoV, in which neurological symptoms tended to appear later during the infection, the milder symptoms of loss of smell or taste typically occurred in the early phase of SARS-CoV-2 infection (Mao et al. 2020a). Cerebrospinal fluid (CSF) may also provide insights regarding the route or site of COVID-19 infection. In a 24-year-old Japanese man who was the first reported case of SARS-CoV-2-associated meningoencephalitis, SARS-CoV-2 RNA was detected not in his initial 


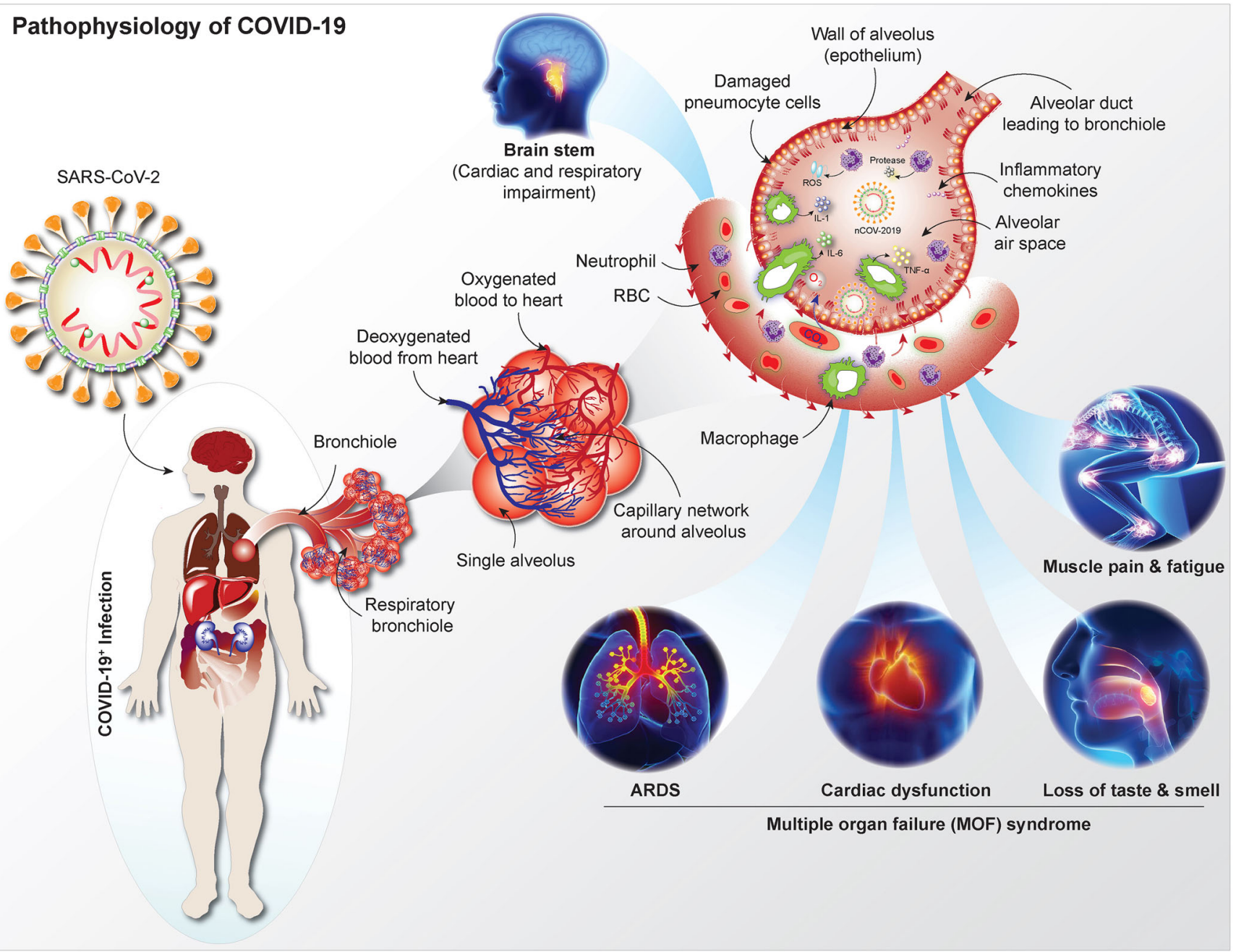

Fig. 5 Pathophysiology of SARS-CoV-2 systemic infection. Infection initiates in the upper respiratory tract and progresses to lower regions of the lung in severe cases. Respiratory droplets carrying SARS-CoV-2 infect epithelial and endothelial cells, neurons, microglia, and lung macrophages containing angiotensin-converting enzyme 2 (ACE-2). Viral replication and release of damage-associated molecular patterns induce pyroptosis, causing a dysfunctional innate immune response. Release of pro-inflammatory agents can induce a cytokine storm, increasing vasodilation, capillary permeability, and hypoxemia that can often lead to multiple organ failure nasopharyngeal swab test but in his CSF instead, and his brain MRI showed the typical abnormalities seen in encephalitis, with hyperintensities along the lateral ventricles, and medial temporal lobes, including the hippocampi (Moriguchi et al. 2020). In contrast, two other cases that involved cerebral hemorrhages, due to a ruptured aneurysm in one and a hemorrhagic conversion of an ischemic stroke in another, might have had viral entries through the nasal cavities, since they showed persistently positive nasal swab for COVID-19, but negative tests on quantitative real-time PCR for SARS-CoV-2 in the CSF (Al Saiegh et al. 2020). Accumulating evidence suggests SARS-CoV-2 might induce intracranial cytokine storm syndrome, which results in breakdown of the blood-brain-barrier (BBB) rather than transynaptic viral CNS invasion (Helms et al. 2020; Poyiadji et al. 2020). Following SARS-CoV-2 infection, activated CD4+ T lymphocytes may secrete a granulocyte-macrophage colony-stimulating factor that induces macrophage to secrete pro-inflammatory cytokines, perpetuating the vicious cycle of the cytokine storm both in the periphery and in the CNS. In support of this model, recent studies demonstrated that SARS-CoV-2 has the potential to infect T lymphocytes (Grifoni et al. 2020; Li et al. 2020a; Park 2020). Thus, SARS-CoV-2 can induce neurological abnormalities either by direct invasion of the CNS or by an indirect intense systemic inflammatory response that leads to a cytokine storm.

Moreover, previous studies established a link between coronavirus infections and neurodegenerative diseases. For instance, coronavirus nucleic acids were detected in the CSF and brain tissue of multiple sclerosis (MS) patients, and coronavirus antigens were implicated in the development of autoimmune responses in MS patients (Murray et al. 1992). Other coronaviruses, CoV-OC43, and CoV-229E, were also found in the CSF of Parkinson's disease patients (Fazzini et al. 
1992). In both neurodegenerative diseases and viral infections, systemic inflammatory mediators may access the CNS and damage the BBB, leading to neurological deficits. Therefore, SARS-CoV-2 infection may further promote the development of neurodegenerative diseases in individuals already at risk for these disorders. Accurate documentation of the neurological symptoms, electrophysiological and radiological examinations, detection of the virus from the CSF, and immunohistology of the brain specimens, are needed to further elucidate the clinical-neuropathological correlations of COVID-19. Understanding systemic and CNS inflammatory responses elicited by the SARS-CoV-2 infection may also guide future treatments for COVID-19 related neurological diseases.

Blood Vessels Recent findings suggest the potential risk of coagulopathy in severe COVID-19 patients, especially in patients with comorbid disease conditions such as hypertension, obesity, cancer, congestive heart failure, cancer, etc. (Barnes et al. 2020; Kollias et al. 2020). Recently, several thrombotic complications including deep vein thrombosis, large vessel stroke, pulmonary embolism, and systemic arterial and venous thromboembolism were reported in 184 patients with severe COVID-19 pneumonia (Klok et al. 2020). Additionally, among 183 hospitalized patients, disseminated intravascular coagulation was observed significantly more common in patients who died of COVID-19 (71\%) as compared to the survivors $(0.6 \%)$ (Tang et al. 2020). It is believed that the "cytokine storms" and increased levels of D-dimer are prime attributes of coagulopathy in the COVID-19 patients (Tang et al. 2020). Recently, the Anticoagulation Forum, a North American organization of anticoagulation providers, recommended a risk of venous thromboembolism in COVID-19 patients and suggested the use of anti-coagulation therapy, primarily low molecular weight heparin, for disease management (Barnes et al. 2020). They recommended to monitory Ddimer levels every day in severe COVID-19 patients during hospital stay to inspect severity and prognosis of thromboembolism, and the dosing intensity of anti-coagulants should be corrected appropriately (Barnes et al. 2020). For COVID-19 patients at risk of thromboembolism, standard thromboprophylaxis treatment is recommended (Barnes et al. 2020; Kollias et al. 2020).

Heart Cardiovascular complications in COVID-19 patients are major contributors to mortality. These comorbidities include arrhythmias, myocardial infarction, and myocardial injury. Though signs of acute coronary syndrome, along with several blood biomarkers indicate progressive heart involvement in the setting of SARS-CoV-2 infection, it is important to note that they comprise a minority of presenting symptoms in COVID-19. Abnormal heart rate has been described in approximately $6-7 \%$ of hospitalized individuals with suspected
COVID-19 (Inciardi et al. 2020; Zeng et al. 2020). Sinus tachycardia, is the most frequently encountered COVID-19 associated arrythmia (Prutkin et al. 2020). Prolonged QTc intervals have also been reported (Richardson et al. 2020). Chloroquine/hydroxychloroquine and azithromycin, which has been tried as a regimen for COVID-19, are each associated with QTc-prolongation (Mercuro et al. 2020) which may induce pleomorphic tachycardia including "torsade de pointes" (Marquardt and Albertson 2001). Myocardial infarction and coronary artery disease complications pose a more significant health concern to COVID-19 patients. Hypertension and coronary artery disease are two risk factors significantly associated with higher COVID-19 mortality (Wang et al. 2020a; Zhou et al. 2020b). Type 2 myocardial infarctions with or without ST segment elevation are most common in COVID19 patients (Pinto et al. 2020). Cardiogenic shock remains a key COVID-19 complication accompanying hypoxia related respiratory failure (Tavazzi et al. 2020). Nonetheless, several biomarkers are notably increased in those experiencing COVID-19 myocardial injury. Plasma cardiac-specific troponin and N-terminal pro hormone brain natriuretic peptide continued to rise among terminal COVID-19 patients compared to survivors (Guo et al. 2020a). The elevated troponin offered prognostic value in predicting malignant arrhythmia, and requirement of mechanical ventilation. Increased levels of Ddimer, interleukin-6, ferritin, and lactate dehydrogenase have been documented as part of the cytokine storm in COVID-19 mortalities (Zhou et al. 2020b). In addition to serial monitoring of blood-based biomarkers, the use of a standard 12-lead electrocardiogram remains a critical tool for the management of myocardial infarction, arrhythmias, and to minimizing overall heart complications secondary to severe COVID-19.

Liver, Gastrointestinal (GI) Tract, and Kidney Considerable data support the notion that SARS-CoV-2 infection commonly affects both the GI tract and the liver (Puelles et al. 2020; Sultan et al. 2020). A recent and more conclusive report that involved a systematic review and meta-analysis of 47 studies and 10,890 patients showed that GI signs and symptoms, including nausea, vomiting, abdominal pain, and diarrhea were observed in up to $10 \%$ of COVID-19-infected patients. Moreover, abnormal liver enzymes were seen in 15-20\% of COVID-19 patients (Sultan et al. 2020). In another metaanalysis from 35 studies, including 6686 COVID-19 patients, 6064 patients reported common GI symptoms such as nausea, vomiting, diarrhea, or loss of appetite (Mao et al. 2020b).

Further subgroup analysis revealed that patients with severe COVID-19 had elevated aminotransferases and bilirubin, but not in the patients with milder symptoms (Mao et al. 2020b). These observations highlight to all health care providers that new-onset GI complaints could indicate an atypical presentation of COVID-19. Patients that are hospitalized would benefit from baseline liver enzyme tests, especially 
since the medications used are often hepatotoxic. SARSCOV-2 has also been identified in the stools of patients with COVID-9 (Xiao et al. 2020). More studies are needed to clarify the usefulness of detection of SARS-CoV-2 in the stools, and its potential impact on the transmission or clinical management of these patients.

Infection of the kidney and kidney dysfunction are likely in patients who present with multi-organ failures. Renal abnormalities associated to COVID-19 include but are not limited to: proteinuria, hematuria, and acute kidney impairments. SARS-CoV-2 is known to infect podocytes and tubular epithelial cells, which could further contribute to renal abnormalities (Martinez-Rojas et al. 2020; Puelles et al. 2020). A non-peer reviewed study of 85 laboratory confirmed COVID-19 patients hospitalized in Wuhan, China, during January 17th, 2020 to March 3rd, 2020, showed acute kidney injury in $27 \%$ of patients and the symptoms were more severe in elderly patients with comorbidities, such as hypertension and heart failure (Diao et al. 2020). Histological examination of the kidneys from six patients with acute renal injury demonstrated severe acute tubular necrosis and infiltration of lymphocytes and macrophages. Virus-like particles were also visible in the kidney, suggesting direct effects of viral infection on the kidney dysfunction (Diao et al. 2020). In another study, kidney abnormalities were observed in 26 autopsies of severely ill COVID-19 patients. Tubular necrosis was observed along with prominent erythrocyte aggregates and ischemic glomeruli, and infiltration of coronavirus-like particles along with inflammatory changes were also observed ( $\mathrm{Su}$ et al. 2020). However, clinical knowledge regarding the pathological effects of SARS-CoV-2 on the kidney remain scarce, and are needed to design preventive and therapeutic strategies against COVID-19.

\section{Social and Societal Considerations}

\section{Psychological Manifestations}

Patients infected with SARS-CoV-2 who suffer from a cytokine storm syndrome frequently incur CNS damage, resulting in neurological disorders and affecting mental health (Poon et al. 2015; Helms et al. 2020; Poyiadji et al. 2020). Approximately $25 \%$ of COVID-19 patients experience central nervous system manifestations. The ongoing progression of SARS-CoV-2 shows similar signs of psychological distress found in SARS and MERS, such as patients suffering from anxiety, impaired attention, impaired memory, and depressed mood in the acute phase of infection and even after the illness (Rogers et al. 2020a). During the MERS outbreak in 2015, one study found that patients had elevated levels of calcium and phosphorous after 14 days of isolation, indicating stress (Torales et al. 2020).

Notably, the broader psychological challenges of SARSCoV-2 extend beyond those who have been infected. Distress is not confined to patients. Wuhan has shown an increase in anxiety and depression due to high-pressure demand for proper hygiene and protection. This is especially true in the case of health care providers affiliated with COVID-19 patients (Torales et al. 2020). Psychological intervention teams were deployed to assist medical professionals in Wuhan due to the increased rates of anxiety, depressive symptoms, insomnia, denial, anger or fear of SARS-CoV-2 (Kang et al. 2020a). In 2003, most emergency department workers in Taiwan developed post-traumatic stress disorder during the SARS-CoV outbreak (Torales et al. 2020). This is not unexpected, as medical professionals were in frequent contact with patients and families experiencing the most severe symptoms of the SARS-CoV-2, and were often unequipped with proper personal protective equipment (PPE) (Mandrola 2020). Many medical professionals were being overworked. Elderly nursing homes were documented to be under staffed to provide care for their residents, resulting in many of the patient deaths (Bruinen de Bruin et al. 2020). By the end of May 2020, over 350,000 people worldwide have died from COVID-19, many of whom were in a hospital with medical professionals unable to provide treatment. The limited availability of PPE coupled with the many unknowns of SARS-CoV-2 could not ensure medical professionals and other frontline workers that they were safe from contracting the virus (Ye et al. 2020a).

Similar to medical professionals, psychological symptoms are found in the general public. The apparent life-threatening need for social distancing and personal hygiene significantly impacted millions of people globally (Fong et al. 2020; WHO $2020 \mathrm{w}$ ). Many governments have implemented some form of social distancing guidelines, given the potential impact it has shown on attenuating cases via various modeling strategies (Kissler et al. 2020). These guidelines typically involve participant gathering restrictions, the mandatory shutdown of socially-based businesses, travel restrictions, and hygiene guidelines, the global socio-economic stressors of SARSCoV-2 are impressive (Torales et al. 2020). In the USA alone, travel agencies have furloughed up to $90 \%$ of their staff. Oil prices went to sub-zero for the first time, a stimulus package costing nearly $\$ 2$ trillion was passed by the U.S. Congress, and predicted economic setbacks are worse than those from World War II (Yamin 2020). Travel bans and quarantine regulations restricted many individuals from contact with family and friends. News about the number of deaths and lack of available care are shown across media outlets without the ability to provide concrete answers on how best to respond. Collectively, the negative forecasting of SARS-CoV-2 without guidance perpetuates stress (Bruinen de Bruin et al. 2020; Nicola et al. 2020). While these measures all aid in preventing 
the spread of SARS-CoV-2, the financial, physical, and personal side-effects can be detrimental to mental health (Nicola et al. 2020; Wu et al. 2020b).

The human need for social connection is well documented. Many health benefits, such as lowered rates of myocardial infarction, have been linked to a healthy social life (Seeman 1996). On the contrary, a lack of contact due to social distancing may create feelings of stress, anxiety, and depression. Declining mental health can exacerbate the risks for exacerbating symptoms of or negative outcomes associated with substance use disorders, as well as for declining function in those with various neurodegenerative diseases, such as Alzheimer's disease (Federico 2020; Singh et al. 2020). Since March 2020, a large shift to support a socially-distanced lifestyle has developed rapidly: University and high school education adopted various online platforms. Many office jobs, conferences and interviews shifted to video-conferencing and telephone calls. In the USA, insurance companies now cover medical consultations via telemedicine using videoconferencing or telephone for mild illnesses and routine follow-ups, rather than in person appointments (Hollander and Carr 2020; Schwamm et al. 2020). Many of these changes will undoubtedly alter the socioeconomic structure after the COVID-19 pandemic has ended. Social distancing laid the groundwork for a heavily internet and computer reliant network for careers and routine daily life (Bruinen de Bruin et al. 2020; Nicola et al. 2020). However, the effects of diminishing person-person contact on a large scale are still uncertain. In 2014, a 3.4-fold increase in neurological disorders was found in a study done after the Boston marathon bombings that resulted in a city-wide lockdown (Guerriero et al. 2014). Given the apparent distress isolation may have, it is imperative to proceed cautiously with social-distancing and dissociation via internet usage.

\section{Social Inequality and Social Determinants of Health (SDOH)}

Social determinants of health may increase the probability of severe COVID-19 health complications for particular segments of the society. "The environment in which people are born, grow, live, work and age" (Braveman and Gottlieb 2014) shape the health of individuals and population demographics. According to the WHO's Commission on the Social Determinants of Health, inequality of health contributes to poor health outcomes for the poor and disadvantaged segments of society (Kelly et al. 2007). The U.S. Office of Disease Prevention and Health Promotion breaks down SDOH into five interrelated categories: economic stability, education, social and community context, health and health care, neighborhood and general environment (ODPHP 2020).
Abundant examples of social stress can be found in news media coverage of the pandemic. Workers in low-paid jobs deemed "essential" such as grocery workers (Dungca et al. 2020; CDC 2020c), meatpacking plant laborers (Schlosser 2020), and waste management personnel found themselves with greater exposure to risk (with limited alternative employment prospects due to the collapse of the labor market). Less affluent students from around the world, who remained sheltered-in-place, found themselves sharing or competing with siblings or parents to use devices necessary for remote learning (NCLD 2020; Zhong 2020). Places for community gathering and entertainment were disrupted without a timeline for returning to normalcy (interfering with affiliated livelihoods and community engagements) as professional sports (Archer 2020), youth athletics (CDC 2020d), funerals (CDC 2020e), music festivals (Vulture 2020; Billboard 2020), religious gatherings (CDC 2020f) amongst others all came to a halt. In the United States, inequality in health is demonstrated by the greater COVID-19 morbidities and mortality in African Americans and Latinos. Health disparities also exposed issues linked to systemic racism as "Black Lives Matter" and racial injustice protests swept the nation and worldwide (Ahmed et al. 2020; Yancy 2020). Lastly, vulnerable and institutionalized groups face heightened risks; homeless indviduals, who are exposed to second-hand cigarette smoke, poor sanitation and diet, suffered greater COVID-19 health-related complications (Baggett et al. 2020; Tsai and Wilson 2020).

\section{Social Discourse during the Pandemic}

Discourse (Foucault 2005/1989) in the tradition of French philosopher and medical historian Michel Foucault refers to subjective knowledge that are intertwined into the structure of society itself. Social hierarchy, beliefs, and values are formed through discourse. Recursive discourse is the process by which discourse reinforces or challenges the structure of a society. The subject of discourse analysis in regard to COVID-19 is a rich subject area with opportunities for further interdisciplinary study between medicine, the social sciences, and humanities. Some examples of society-linked political discourse with health implications for the general public include:

- During a period of strained United States-China trade relations, politicians using racially charged terms to refer to SARS-CoV-2 (for example, calling SARS-CoV-2 the "the Chinese virus" or "Kung Flu") contribute to an atmosphere of heightened racism and Sinophobia. Such phrasing could be construed as insults directed at ethnic Chinese citizens, immigrants, and international students (Chiu 2020; LaMonica 2020; Rogers et al. 2020b). 
- Community and government leaders who encouraged resistance to public health guidelines for social distancing and wearing face coverings (on the basis of concern for the infringement of individual liberty) exposed adherents to greater risk of contracting and transmitting SARS-CoV-2 (Vandell 2020).

- Politicians and governments were canceling protests or silencing political dissent on the grounds of COVID-19 health precautions (for example, the Hong Kong Special Administrative Region government's denial of a protest permit for the city's Tiananmen Square vigil for first time in 30 years, citing COVID-19 concerns) (Chung and Chik 2020).

- Conspiracy theories, misinformation, and opportunistic vendors of products capitalizing on the public health crisis through social channels (Ball and Maxmen 2020; Association for Psychological Science 2020).

\section{Pediatric Populations}

The rapidly spreading COVID-19 virus has infected individuals of all ages across the world. Pediatric populations appear comparatively less vulnerable to SARS-CoV-2 infection than adults, with only $2 \%$ of the cases reported under age 20 years. An epidemiological study from China reported 2135 pediatric patients with COVID-19 hospitalized between January 16 th to February 8 th, 2020. From this cohort, $728(34.1 \%)$ were laboratoryconfirmed cases, while 1407 (65.9\%) were suspected cases. No significant sex difference was observed, and amongst these cases, more than $90 \%$ were asymptomatic, mild, or moderate (Dong et al. 2020b; Lu et al. 2020b). In the United States, between February 12th to April 2nd $2020,2572(1.7 \%)$ of 149,760 laboratory-confirmed COVID-19 cases were pediatric patients aged below 18 years; $73 \%$ of these pediatric patients had symptoms of fever, cough, and shortness of breath (like the symptoms in the adults), with only three deaths reported (CDC $2020 \mathrm{~g})$. However, several recent cases of pediatric patients were reported across the country with uncommon pediatric multi-system inflammatory syndrome likely linked to COVID-19. This inflammatory syndrome has features that overlap with those seen in Kawasaki disease and in toxic shock syndrome, which may occur days to weeks after the acute COVID-19 illness (Jones et al. 2020; Russo 2020). Italy, Spain, and the U.K. have noted an uptick in this Kawasaki-like disease among children coincident with COVID-19 (Stancati and Douglas 2020). These children typically experienced fever, low energy, and loss of appetite, with overlapping rashes on the body, and extra reddish lips and tongues, which are the classical symptoms of Kawasaki disease (Fig. 6). Although the disease is rarely life-threatening, it can cause lasting heart complications if left untreated. Kawasaki disease was first identified in Japan and had been traced to the croplands of northeastern China (Rodo et al. 2014). The first known published case of classic Kawasaki disease associated with COVID-19 was reported by the Stanford Health Care Clinical Virology Laboratory in late April 2020. A 6-month-old who had screened positive for COVID-19 presented with fever, limbic sparing conjunctivitis, prominent tongue papilla, a blanching, polymorphous, maculopapular rash, and swelling of the hands and lower extremities with blotchy rash, but minimal respiratory symptoms. No cardiovascular complications were observed. After the child was treated with intravenous immunoglobulin (IVIG) and high dose aspirin, she was well enough to be discharged (Jones et al. 2020). Health organizations have started warning about the unusual presentations of a Kawasaki disease-like inflammatory syndrome associated with COVID-19 in pediatric patients. Since the full clinical spectrum is yet to be clearly defined, such pediatric patients presenting with fever alone, or primarily with other organ system involvements, may be missed if testing is restricted to those with respiratory complaints alone (Jones et al. 2020).

\section{Current Disease Management}

There are currently limited therapeutic options for SARSCoV-2 beyond supportive care, a limitation made more complicated by the intense occupational challenges facing healthcare providers. There are no proven effective vaccines or therapeutic agents to protect against the infection or to treat the viral infection. Current clinical management includes prevention or treatment of comorbid infections and respiratory control measures. The latter includes supplemental oxygen and, when necessary, mechanical ventilatory support or extracorporeal membrane oxygenation (Wu et al. 2020c). A number of repurposed drugs have been touted for the treatment of SARS-CoV-2 with known or unleashed "anecdotal" therapeutic efficacies in treating those with COVID-19 disease. These include, but are not limited to, the antiviral agents remdesivir, hydroxychloroquine, chloroquine, lopinavir, favipiravir, and oseltamivir (McCreary and Pogue 2020; Sanders et al. 2020). Of these, only remdesivir showed a modest positive result for shortened course of illness (Beigel et al. 2020; Grein et al. 2020) and reduced the mortality from COVID-19 in the SIMPLE-severe study (presented at the recent International AIDS conference's virtual COVID-19 conference) (Gilead, 2020) . Adjunctive medications, including azithromycin, corticosteroids, dexamethasone and 


\section{COVID-19 and Kawasaki disease?}

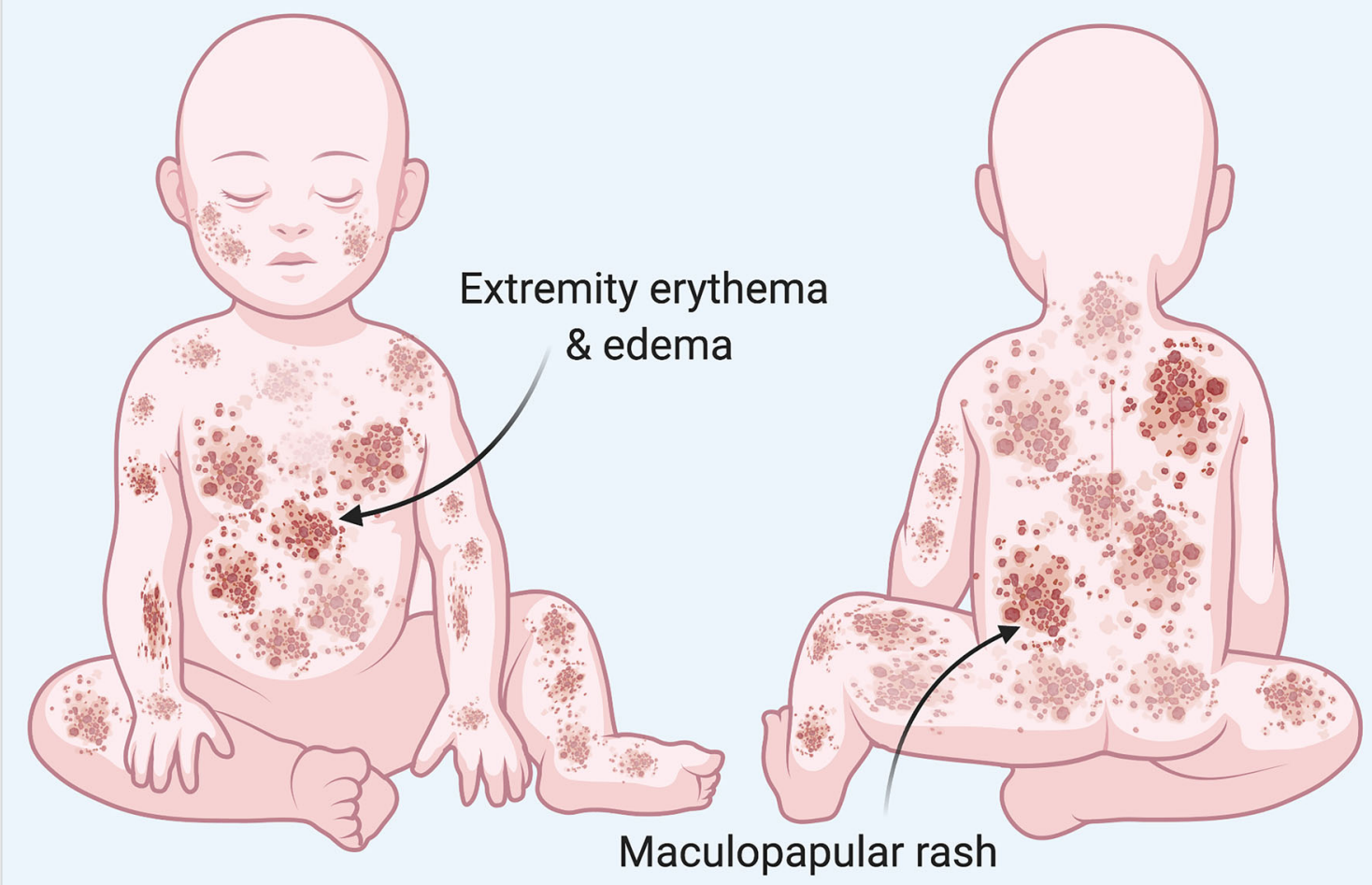

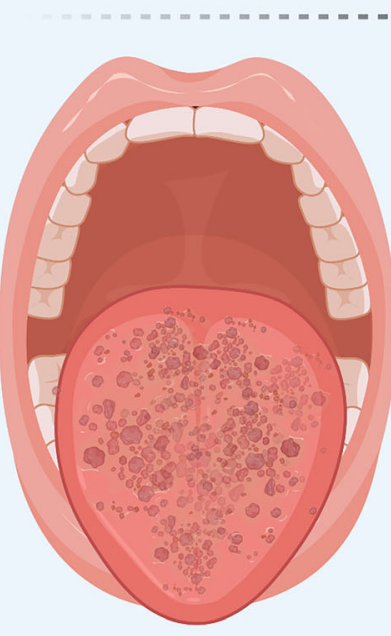

Tongue rash

\section{Eye infection}

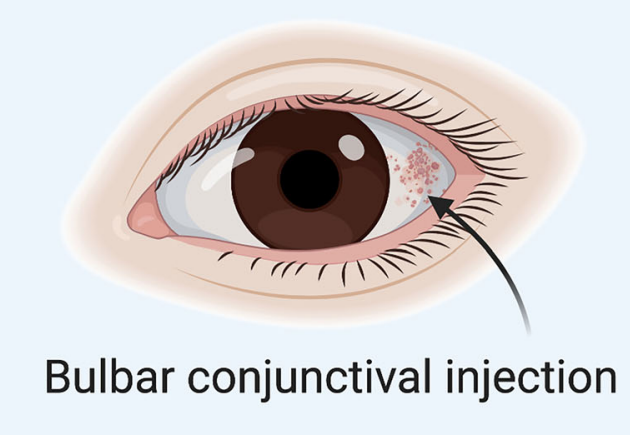

Rash in hand \& feet
Fig. 6 SARS-CoV-2 and Kawasaki disease. SARS-Cov-2 infected pediatric patients show multi-system inflammatory syndrome with symptoms overlapping to the Kawasaki disease. Patients show a diffuse maculopapular rash with swelling on the hands and feet. Extra-reddish tongue and lips and bulbar conjunctivitis are symptoms. Disease, while of unknown cause, affected children under 5 years old. Relationship between Kawasaki disease and SARS-CoV-2 infection is noteworthy. The

IL-6 antagonists, were also used with mixed results (McCreary and Pogue 2020; Sanders et al. 2020). For now, what remains is supportive and preventative care and emergency use of remdesevir (FDA 2020; Beigel et al. 2020; Grein et al. 2020).
Kawasaki disease with SARS-CoV-2 infection is characterized by vasculitis with fever and generalized rash not responsive to conventional antiinflammatory medicines. Associated signs and symptoms include enlarged lymph nodes, inflamed lips, palms, eyes, and soles of the feet. In weeks after disease onset, there is exfoliation of the hands and feet. Coronary artery aneurysms can form with an autoimmune response

For individuals who contracted COVID-19 and receives care at home, the Center for Disease Control (CDC) guidance for at-home care of individuals with COVID-19 include: isolating the sick person, wearing face masks, frequent hand washing, and daily disinfection of hard surfaces (CDC 
2020h). Quarantine is also advised in order to "keep an exposed person at a distant from others," while isolation is urged to separate virus infected people (those who are ill with COVID-19 disease or those infected without symptoms) from people who are not infected" (CDC 2020i, j). Recommended preventative care strategies would include: physical distancing (enabling at least $6 \mathrm{ft}$ from others or about two arms' length distance); not touching the face, eyes, nose, ears or mouth; wearing a cloth face mask; frequently clean and disinfect objcts and surfaces; staying home when sick or leaving when medical care is required; and washing of hands with soap and water for at least $20 \mathrm{~s}$ (CDC 2020k). Community mitigation strategies can slow the spread of the virus and protect individuals at risk for the illness. Community mitigation strategies are broad and extend from "shelter in place" when community transmission is operative to "lower mitigation" when no-to-minimal community risk for transmission is operative (CDC 20201, m).

\section{COVID-19: Living Past a Near Death Experience}

The impact of the viral pandemic beyond a nation, community and society is reflected by the individual. The shared life experience written by a patient who successfully recovered from COVID-19 underpins the impact of the disease to the individual and his or her family. To this end Peter "Paul" Kline shared this first-hand account of his illness, hospitalization and near death experience towards providing insights on the clinical management of COVID-19 from the perspective of an individual. The life event is captured as follows, as recounted by the patient himself. "After battling what felt like the flu for about a week, I woke up right before midnight Tuesday, March 31st, 2020, and noticed it required an effort to breathe. It was subtle and didn't feel like an emergency. Maybe I was just tired, I thought. After all, I had already been in bed for a week with a fever, fatigue, and sweats. The cough started a few days prior. Trusting my wife's advice, I called the doctor. Again.

It would be the fourth or fifth time I had called the doctor's office and wasn't expecting any new insights. For the past week, each time I called and requested to be examined and tested for coronavirus, I had been denied. The office told me to fill out the online questionnaire and if I checked the right boxes, then I could be seen. I hadn't been around a large crowd within the past month, and I hadn't traveled to China. I am not old, nor do I have any underlying health issues. So, no test was needed. I was told to drink fluids and take Tylenol. Besides, coming into the office could be risky because I might expose myself to others who were infected.

But that night the doctor on call said something different go to the emergency room. We debated if it was worth it. Maybe I should just wait until the morning. I wasn't up to driving myself. If I really was infected then calling the
EMTs might expose them. Would that be selfish? My wife couldn't drive me; who would watch the kids? We decided to call.

While waiting for the paramedics, I got dressed and walked outside to wait in front. I did not want them to wake up my kids. I only mention that part to emphasize that I was able to walk around and merely felt tired. The impact on my breathing at that point was minor. On the way to the hospital, they measured my oxygen levels and mentioned it was low so they put me on oxygen while on route. I don't know the exact level because I wasn't paying that close attention to it, but I vaguely remember the paramedic on the radio reporting something in the 80 s. They definitely didn't seem alarmed. Thankfully, they brought me right into an exam room upon arrival, where they took my vitals including oxygen levels again. They administered the nasal swab test and performed a chest $\mathrm{x}$-ray. They put me on what I remember them describing as "a lot" (five liters) of oxygen. It's tough to remember the exact numbers but I do remember looking over my shoulder at the monitor and it bounced around from high 80s-90. I kept taking deep breaths to try and make it go higher.

When the doctor came in a little later, he confided that the chest x-ray didn't look good, nor did my oxygen levels. They may have to intubate me. "What does that mean?" I asked. "It means we put you in a coma and hook you up to a ventilator."

"Can't you just give me some oxygen? I don't feel so bad." "Look, I am treating you like you have COVID-19. I've seen enough of these cases and around the fifth or sixth day we have seen people's lungs give out. I would rather do this now to preserve your lungs than have to do it when it's a total emergency. You're a young guy and you have a good chance of a recovery and coming off the ventilator."

It seemed reasonable enough at the time, sitting there at 1:00 a.m. exhausted and fatigued after being sick for a week. How could I argue? He's the doctor. Looking back on it, how amazing that I wasn't terrified. An act of Divine Mercy prevented fear from sinking in at that moment. "How much time do I have?" "You have about 20 minutes. Call who you need to call." I called and texted family and close friends and colleagues to let them know what was going on. I am about to be put on a ventilator. Please pray for me. They brought me to a different room and a team in full biohazard gear arrived. First, I remember them giving me ketamine to tranquilize me. Next, they put intravenous (IV) lines in both arms. I don't remember the IV being put into my neck. By that time, I was already unconscious. I had the foresight to ask, "Wouldn't it be a good idea to take my contact lenses out?" and the doctors agreed.

I awoke in a totally different setting. Later, I learned that they had transferred me to the ICU of a totally different hospital. I don't know exactly for how long I was out. And the memories from this point while sedated are a bit hazier but a few stick out quite clearly. 
My best guess is I woke up sometime on that Thursday - which would have been about $36 \mathrm{~h}$ later. I don't know why I woke up, but I think the doctors intended to do so to try and begin the process of taking me off the ventilator which in hindsight seemed ironic (didn't they just put me on it). With my hands strapped to the sides of the bed, I was unable to move my arms (to prevent me from pulling out the breathing apparatus). With tubes down my throat, I couldn't talk. I rapped on the side of the bed with my wrist to get the nurse's attention and made a motion to write. She realized I wanted to write and brought me some pen and paper.

Now, I had to write with my hand at arm's length and with no contact lenses in. So I couldn't really see the paper. I wish more than anything I had kept those notes I wrote. What day is it? What is the prognosis? How are you treating me? Besides being informed of the day, they left me guessing on the rest. "Another dose of fentanyl..." Fentanyl was about the only drug they were putting me on that I had heard of. When I overheard that I wrote: "NO MORE FENTANYL PLEASE GIVE ME TYLENOL." I had read about that drug and didn't want to have any of it in my body. I wanted to be awake even if it meant being uncomfortable. One time the nurse came in to tell me she was calling my mother back and what would I like to tell her. I wrote a short letter. "Mom, I love you. Don't worry. God is holding my hand. Love, Paul." Each day they came to inject me with a drug into my stomach which was particularly uncomfortable. I was told it was to prevent blood clots.

They employed a special suction tube/device down my throat to help remove the fluid/mucous from my lungs. I don't know how it worked exactly, but in part it was a manual process whereby they inserted it and drew out the fluid. I coughed and coughed and they would draw it out. When I understood that this was helping me get the fluid out, I asked again and again for them to do it despite how uncomfortable the process was and how it brought on more coughing. It was a little bit of extra self-help.

They told me they were going to do a breathing test and if I passed, they may try and take out the ventilator. What a buildup. Do I still know how to breathe? Yes. With each breath I thanked God. Oxygen looked good. It went well. I wrote: "so now you can take me off?" "No, now you need to rest. Maybe we will try tomorrow." What a letdown!

Most of the nurses were some of the most caring people I've ever met. There were a few exceptions but it's not worth retelling that part. While hooked up, I experienced quite vivid and personal hallucinations. The sedatives and ventilator made me feel detached from reality. I knew most of it was hallucination while it was happening. What a weird and horrible feeling. I was desperate to get off these medications. I spent much of my conscious time praying. Every day I felt like my condition improved, with the exception of the first or second night when my fever spiked. I lay there convulsing with a fever ("103" ... did I hear/remember that correctly?) and through the whole experience that was the only moment when I doubted whether I would survive. I was not afraid of dying, but I was afraid for my family. Each day, I dreamed of a nice cold glass of ice water, or better yet just a Coca-Cola.

On Monday April 5th, 2020, around mid-day they extubated me. I was breathing perfectly but they kept me on oxygen. I was able to stand up with some help and moved to a chair. That was the best cold water I ever tasted. The recovery after coming off the ventilator was also very difficult. My stomach was so bloated and in so much pain I could hardly move. They pumped some sort of goop-like food into me for a week straight and besides being on a catheter I obviously hadn't used the bathroom. One of the most jarring experiences throughout the ordeal happened when one of the nurses informed me that I had been listed as a DNR ("do not resuscitate") and wanted to double check if that was correct. I am 37, married with 3 young children. How could they have that on my file? Did they ask me while I was under the influence of sedation unawares of my response? Was it done without my consent? I intend to find out. They transferred me into the regular hospital room that night. I remained with an IV receiving antibiotics to combat the bacterial pneumonia contracted while in the ICU. I had no fever and my oxygen and breathing were completely normal. But, the following 2 nights were exceedingly difficult. My skin felt like it was burning, I was sweating, and every time I closed my eyes, I saw intense psychedelic hallucinations, including at one point what looked like spiders attacking me. I called the nurse to come take my temperature because I was sure something was wrong, but was assured that everything was totally normal.

Further, the hospital bed was miserable. It was designed to prevent bed sores and aid circulation. No matter how I set it, it constantly squirmed and readjusted under me guaranteeing I would never get comfortable. I didn't sleep the whole first night, moving from chair to bed and back again. I was nearly manic by the second day but the nurse's only recommendation was I take some melatonin and Ativan. I woke up an hour later with all the same symptoms. By the second day after no sleep I was totally manic and told them as soon as the IV runs out I am leaving no matter what because the hospital prevented my recovery. I fished out the clothes I came in with and got dressed even while the IV was still in my arm. From the best I can tell, I was experiencing some type of withdrawal symptoms from going cold turkey off all the heavy medication (fentanyl) I had been on for almost an entire week. Or maybe it was side effects of the ventilator? Nobody addressed it. I came home from the hospital in the afternoon of April 8th, 2020, after eight nights (six of those nights on a ventilator). We still don't know where I contracted the virus. I had been sheltering in place for about 2 weeks prior to the onset of symptoms. Was the decision to put me on the ventilator the 
right one? I don't know, but I thank God every day I survived. Many weren't as fortunate."

Acknowledgments This work was supported by the National Institutes of Health R01 AG043530, P01 DA028555, P30 MH062261, R01 MH115860, R01 NS034249, R01 NS036126, and the Carol Swartz Emerging Neuroscience Fund.

\section{References}

Abdullah AS, Tomlinson B, Cockram CS, Thomas GN (2003) Lessons from the severe acute respiratory syndrome outbreak in Hong Kong. Emerg Infect Dis 9:1042-1045

Ahmed F, Ahmed N, Pissarides C, Stiglitz J (2020) Why inequality could spread COVID-19. Lancet Public Health 5:e240

Al Saiegh F, Ghosh R, Leibold A, Avery MB, Schmidt RF, Theofanis T, Mouchtouris N, Philipp L, Peiper SC, Wang ZX, Rincon F, Tjoumakaris SI, Jabbour P, Rosenwasser RH, Gooch MR (2020) Status of SARS-CoV-2 in cerebrospinal fluid of patients with COVID-19 and stroke. J Neurol Neurosurg Psychiatry

Angelini MM, Akhlaghpour M, Neuman BW, Buchmeier MJ (2013) Severe acute respiratory syndrome coronavirus nonstructural proteins 3, 4, and 6 induce double-membrane vesicles. mBio 4: e00524-e00513

Archer T (2020) Coronavirus cancellations and reactions in sports. ESPN. https://www.espn.com/espn/story/ /id/28871525/coronaviruscancellations-reactions-sports

Association for Psychological Science (2020) Psychological Science and COVID-19: conspiracy theories. newswire. https://www.newswise. $\mathrm{com} /$ coronavirus/psychological-science-and-covid-19-conspiracytheories/?article id=732369

Backer JA, Klinkenberg D, Wallinga J (2020) Incubation period of 2019 novel coronavirus (2019-nCoV) infections among travellers from Wuhan, China, 20-28 January 2020. Eurosurveillance 25:2000062

Baggett TP, Keyes H, Sporn N, Gaeta JM (2020) Prevalence of SARSCoV-2 infection in residents of a large homeless shelter in Boston. JAMA 323:2191-2192

Baig AM, Khaleeq A, Ali U, Syeda H (2020) Evidence of the COVID-19 virus targeting the CNS: tissue distribution, host-virus interaction, and proposed neurotropic mechanisms. ACS Chem Neurosci 11: 995-998

Ball P, Maxmen A (2020) The epic battle against coronavirus misinformation and conspiracy theories. Nature 581:371-374

Barnes GD, Burnett A, Allen A, Blumenstein M, Clark NP, Cuker A, Dager WE, Deitelzweig SB, Ellsworth S, Garcia D, Kaatz S, Minichiello T (2020) Thromboembolism and anticoagulant therapy during the COVID-19 pandemic: interim clinical guidance from the anticoagulation forum. J Thromb Thrombolysis 50:72-81

Beigel JH et al (2020) Remdesivir for the treatment of Covid-19 - preliminary report. N Engl J Med

Bolles M, Donaldson E, Baric R (2011) SARS-CoV and emergent coronaviruses: viral determinants of interspecies transmission. Curr Opin Virol 1:624-634

Bosch BJ, van der Zee R, de Haan CA, Rottier PJ (2003) The coronavirus spike protein is a class I virus fusion protein: structural and functional characterization of the fusion core complex. J Virol 77:88018811

Braveman P, Gottlieb L (2014) The social determinants of health: it's time to consider the causes of the causes. Public Health Rep 129(Suppl 2): 19-31

Britannica E (2020) Coronavirus: VIRUS GROUP. https://www. britannica.com/science/coronavirus-virus-group
Bruinen de Bruin Y, Lequarre AS, McCourt J, Clevestig P, Pigazzani F, Zare Jeddi M, Colosio C, Goulart M (2020) Initial impacts of global risk mitigation measures taken during the combatting of the COVID-19 pandemic. Saf Sci: 104773

Cao B et al (2020) A trial of Lopinavir-ritonavir in adults hospitalized with severe Covid-19. N Engl J Med 382:1787-1799

Centers for Disease Control and Prevention (2020a) Information for Healthcare Professionals about coronavirus (COVID-19). https:// www.cdc.gov/coronavirus/2019-nCoV/hcp/index.html

Centers for Disease Control and Prevention (2020b) Symptoms of coronavirus. Coronavirus Disease 2019 (COVID-19). https://www.cdc. gov/coronavirus/2019-ncov/symptoms-testing/symptoms.html

Centers for Disease Control and Prevention (2020c) What grocery and food retail workers need to know about COVID-19. https://www. cdc.gov/coronavirus/2019-ncov/community/organizations/groceryfood-retail-workers.html

Centers for Disease Control and Prevention (2020d) Considerations for Youth Sports. https://www.cdc.gov/coronavirus/2019-ncov/ community/schools-childcare/youth-sports.html

Centers for Disease Control and Prevention (2020e) Funeral guidance for individuals and families. https://www.cdc.gov/coronavirus/2019ncov/daily-life-coping/funeral-guidance.html

Centers for Disease Control and Prevention (2020f) Interim guidance for communities of faith. https://www.cdc.gov/coronavirus/2019-ncov/ community/faith-based.html

Centers for Disease Control and Prevention (2020g) Coronavirus disease 2019 in children - United States, February 12-April 2, 2020. Morbid Mortal Wkly Rep 69:422-426. https://www.cdc.gov/ mmwr/volumes/69/wr/mm6914e4.htm

Centers for Disease Control and Prevention (2020h) Taking care of sick people with COVID-19 illness at home. https://www.cdc.gov/ coronavirus/2019-ncov/downloads/global-covid-19/A_HB Carekit_JobAid_508C.pdf

Centers for Disease Control and Prevention (2020i) How are quarantine and isolation different? https://www.cdc.gov/coronavirus/2019ncov/if-you-are-sick/quarantine-isolation.html

Centers for Disease Control and Prevention (2020j) COVID-19: quarantine vs. isolation. https://www.cdc.gov/coronavirus/2019-ncov/ downloads/if-you-are-sick/317422-A_Quarantine-and-Isolation 508.pdf

Centers for Disease Control and Prevention (2020k) Stop the spread of germs. https://www.cdc.gov/coronavirus/2019-ncov/downloads/ stop-the-spread-of-germs.pdf

Centers for Disease Control and Prevention (20201) Implementation of mitigation strategies for communities with local COVID-19 transmission. https://www.cdc.gov/coronavirus/2019-ncov/community/ community-mitigation.html

Centers for Disease Control and Prevention (2020m) CDC activities and initiatives supporting the COVID-19 response and the President's plan for opening America up again. https://www.cdc.gov/ coronavirus/2019-ncov/downloads/php/CDC-Activities-Initiativesfor-COVID-19-Response.pdf

Chen J, Qi T, Liu L, Ling Y, Qian Z, Li T, Li F, Xu Q, Zhang Y, Xu S, Song Z, Zeng Y, Shen Y, Shi Y, Zhu T, Lu H (2020a) Clinical progression of patients with COVID-19 in Shanghai, China. J Inf Secur 80:e1-e6

Chen N, Zhou M, Dong X, Qu J, Gong F, Han Y, Qiu Y, Wang J, Liu Y, Wei Y, Xia J, Yu T, Zhang X, Zhang L (2020b) Epidemiological and clinical characteristics of 99 cases of 2019 novel coronavirus pneumonia in Wuhan, China: a descriptive study. Lancet 395:507-513

Chiu A (2020) Trump has no qualms about calling coronavirus the 'Chinese Virus.' That's a dangerous attitude, experts say. The Washington Post. https://www.washingtonpost.com/nation/2020/ 03/20/coronavirus-trump-chinese-virus/ 
Cho SY et al (2016) MERS-CoV outbreak following a single patient exposure in an emergency room in South Korea: an epidemiological outbreak study. Lancet 388:994-1001

Chu DKW, Pan Y, Cheng SMS, Hui KPY, Krishnan P, Liu Y, Ng DYM, Wan CKC, Yang P, Wang Q, Peiris M, Poon LLM (2020) Molecular diagnosis of a Novel Coronavirus (2019-nCoV) causing an outbreak of pneumonia. Clin Chem 66:549-555

Chung K, Chik H (2020) Hong Kong police ban city's annual Tiananmen Square vigil for first time in 30 years, citing Covid-19 threat. South China Morning Post. https://www.scmp.com/news/hong-kong/ politics/article/3086982/hong-kong-police-cite-covid-19-threatbanning-annual

Coleman CM, Frieman MB (2014) Coronaviruses: important emerging human pathogens. J Virol 88:5209-5212

Cui J, Li F, Shi ZL (2019a) Origin and evolution of pathogenic coronaviruses. Nat Rev Microbiol 17:181-192

Cui J, Li F, Shi Z-L (2019b) Origin and evolution of pathogenic coronaviruses. Nat Rev Microbiol 17:181-192

de Groot RJ, Baker SC, Baric RS, Brown CS, Drosten C, Enjuanes L, Fouchier RAM, Galiano M, Gorbalenya AE, Memish ZA, Perlman S, Poon LLM, Snijder EJ, Stephens GM, Woo PCY, Zaki AM, Zambon M, Ziebuhr J (2013) Middle East respiratory syndrome coronavirus (MERS-CoV): announcement of the Coronavirus study group. J Virol 87:7790-7792

de Haan CA, de Wit M, Kuo L, Montalto-Morrison C, Haagmans BL, Weiss SR, Masters PS, Rottier PJ (2003) The glycosylation status of the murine hepatitis coronavirus M protein affects the interferogenic capacity of the virus in vitro and its ability to replicate in the liver but not the brain. Virology 312:395-406

de Wit E, van Doremalen N, Falzarano D, Munster VJ (2016) SARS and MERS: recent insights into emerging coronaviruses. Nat Rev Microbiol 14:523-534

Diao B, Wang C, Wang R, Feng Z, Tan Y, Wang H, Wang C, Liu L, Liu Y, Liu Y, Wang G, Yuan Z, Ren L, Wu Y, Chen Y (2020) Human kidney is a target for novel severe acute respiratory syndrome Coronavirus 2 (SARS-CoV-2) infection. medRxiv

Dietz L, Horve PF, Coil DA, Fretz M, Eisen JA, Van Den Wymelenberg K (2020) 2019 Novel Coronavirus (COVID-19) pandemic: built environment considerations to reduce transmission. mSystems 5: e00245-e00220

Dong E, Du H, Gardner L (2020a) An interactive web-based dashboard to track COVID-19 in real time. Lancet Infect Dis 20:533-534

Dong Y, Mo X, Hu Y, Qi X, Jiang F, Jiang Z, Tong S (2020b) Epidemiology of COVID-19 among children in China. Pediatrics 145:e20200702

Dungca N, Abelson J, Bhattarai A, Kornfield M (2020) On the front lines of the pandemic, grocery workers are in the dark about risks. The Washington Post. https://www.washingtonpost.com/investigations/ 2020/05/24/grocery-workers-coronavirus-risks/?arc404=true

Duong L, Xu P, Liu A (2020) Meningoencephalitis without respiratory failure in a young female patient with COVID-19 infection in downtown Los Angeles, early April 2020. Brain Behav Immun 20: 30509-30502

Eliezer M, Hautefort C, Hamel AL, Verillaud B, Herman P, Houdart E, Eloit C (2020) Sudden and complete olfactory loss function as a possible symptom of COVID-19. JAMA Otolaryngol Head Neck Surg

Fazzini E, Fleming J, Fahn S (1992) Cerebrospinal fluid antibodies to coronavirus in patients with Parkinson's disease. Mov Disord 7:153158

Federico A (2020) Brain awareness week, CoVID-19 infection and neurological sciences. Neurol Sci 41:747-748

Fehr AR, Perlman S (2015) Coronaviruses: an overview of their replication and pathogenesis. Methods Mol Biol 1282:1-23

Fong MW, Gao H, Wong JY, Xiao J, Shiu EYC, Ryu S, Cowling BJ (2020) Nonpharmaceutical measures for pandemic influenza in nonhealthcare settings-social distancing measures. Emerg Infect Dis 26:976-984

Foucault M (2005/1989) Archaeology of knowledge, 4th edn. Routledge, London

Fukushi M, Yoshinaka Y, Matsuoka Y, Hatakeyama S, Ishizaka Y, Kirikae T, Sasazuki T, Miyoshi-Akiyama T (2012) Monitoring of $\mathrm{S}$ protein maturation in the endoplasmic reticulum by calnexin is important for the infectivity of severe acute respiratory syndrome coronavirus. J Virol 86:11745-11753

Fung TS, Liu DX (2018) Post-translational modifications of coronavirus proteins: roles and function. Futur Virol 13:405-430

Gandhi M, Yokoe DS, Havlir DV (2020) Asymptomatic transmission, the Achilles' heel of current strategies to control Covid-19. N Engl J Med 382:2158-2160

Gao Y et al (2020) Structure of the RNA-dependent RNA polymerase from COVID-19 virus. Science 368:779-782

Gorbalenya AE, Krupovic M, Mushegian A, et al (2020) The new scope of virus taxonomy: partitioning the virosphere into 15 hierarchical ranks. Nat Microbiol 5:668-674

Grein J et al (2020) Compassionate use of Remdesivir for patients with severe Covid-19. N Engl J Med 382:2327-2336

Grifoni A, Weiskopf D, Ramirez SI, Mateus J, Dan JM, Moderbacher CR, Rawlings SA, Sutherland A, Premkumar L, Jadi RS, Marrama D, de Silva AM, Frazier A, Carlin C, Greenbaum JA, Peters B, Krammer F, Smith DM, Crotty S, Sette A (2020) Targets of T cell responses to SARS-CoV-2 coronavirus in humans with COVID-19 disease and unexposed individuals. Cell 20:30610-30613

$\mathrm{Gu} \mathrm{J}$ et al (2005) Multiple organ infection and the pathogenesis of SARS. J Exp Med 202:415-424

Guerriero RM, Pier DB, de Gusmao CM, Bernson-Leung ME, Maski KP, Urion DK, Waugh JL (2014) Increased pediatric functional neurological symptom disorders after the Boston marathon bombings: a case series. Pediatr Neurol 51:619-623

Guo T, Fan Y, Chen M, Wu X, Zhang L, He T, Wang H, Wan J, Wang X,

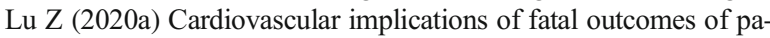
tients with Coronavirus disease 2019 (COVID-19). JAMA Cardiol

Guo Y-R, Cao Q-D, Hong Z-S, Tan Y-Y, Chen S-D, Jin H-J, Tan K-S, Wang D-Y, Yan Y (2020b) The origin, transmission and clinical therapies on coronavirus disease 2019 (COVID-19) outbreak - an update on the status. Mil Med Res 7:11

Han DP, Lohani M, Cho MW (2007) Specific asparagine-linked glycosylation sites are critical for DC-SIGN- and L-SIGN-mediated severe acute respiratory syndrome coronavirus entry. J Virol 81: 12029-12039

Helms J, Kremer S, Merdji H, Clere-Jehl R, Schenck M, Kummerlen C, Collange O, Boulay C, Fafi-Kremer S, Ohana M, Anheim M, Meziani F (2020) Neurologic features in severe SARS-CoV-2 infection. N Engl J Med 382:2268-2270

Hoffmann M, Kleine-Weber H, Schroeder S, Kruger N, Herrler T, Erichsen S, Schiergens TS, Herrler G, Wu NH, Nitsche A, Muller MA, Drosten C, Pohlmann S (2020) SARS-CoV-2 cell entry depends on ACE2 and TMPRSS2 and is blocked by a clinically proven protease inhibitor. Cell 181:271-280

Hollander JE, Carr BG (2020) Virtually perfect? Telemedicine for Covid19. N Engl J Med 382:1679-1681

Hon KL, Leung CW, Cheng WT, Chan PK, Chu WC, Kwan YW, Li AM, Fong NC, Ng PC, Chiu MC, Li CK, Tam JS, Fok TF (2003) Clinical presentations and outcome of severe acute respiratory syndrome in children. Lancet 361:1701-1703

Huang C et al (2020) Clinical features of patients infected with 2019 novel coronavirus in Wuhan, China. Lancet 395:497-506

Hung LS (2003) The SARS epidemic in Hong Kong: what lessons have we learned? J R Soc Med 96:374-378

Hung EC, Chim SS, Chan PK, Tong YK, Ng EK, Chiu RW, Leung CB, Sung JJ, Tam JS, Lo YM (2003) Detection of SARS coronavirus 
RNA in the cerebrospinal fluid of a patient with severe acute respiratory syndrome. Clin Chem 49:2108-2109

Inciardi RM, Lupi L, Zaccone G, Italia L, Raffo M, Tomasoni D, Cani DS, Cerini M, Farina D, Gavazzi E, Maroldi R, Adamo M, Ammirati E, Sinagra G, Lombardi CM, Metra M (2020) Cardiac involvement in a patient with Coronavirus disease 2019 (COVID19). JAMA Cardiol

Irigoyen N, Firth AE, Jones JD, Chung BY, Siddell SG, Brierley I (2016) High-resolution analysis of Coronavirus gene expression by RNA sequencing and ribosome profiling. PLoS Pathog 12:e1005473

Jones VG, Mills M, Suarez D, Hogan CA, Yeh D, Bradley Segal J, Nguyen EL, Barsh GR, Maskatia S, Mathew R (2020) COVID-19 and Kawasaki disease: novel virus and novel case. Hosp Pediatr 10: $537-540$

Kang L, Li Y, Hu S, Chen M, Yang C, Yang BX, Wang Y, Hu J, Lai J, Ma X, Chen J, Guan L, Wang G, Ma H, Liu Z (2020a) The mental health of medical workers in Wuhan, China dealing with the 2019 novel coronavirus. Lancet Psychiatry 7:e14

Kang S, Yang M, Hong Z, Zhang L, Huang Z, Chen X, He S, Zhou Z, Zhou Z, Chen Q, Yan Y, Zhang C, Shan H, Chen S (2020b) Crystal structure of SARS-CoV-2 nucleocapsid protein RNA binding domain reveals potential unique drug targeting sites. Acta Pharm Sin B

Kelly MP, Morgan A, Bonnefoy J, Butt J, V. Bergman, World Health Organization (2007) The social determinants of health: developing an evidence base for political action. Final report of the Measurement and Evidence Knowledge Network to the World Health Organization Commission on the Social Determinants of Health

Khailany RA, Safdar M, Ozaslan M (2020) Genomic characterization of a novel SARS-CoV-2. Gene Rep:100682

Kim D, Lee JY, Yang JS, Kim JW, Kim VN, Chang H (2020) The architecture of SARS-CoV-2 transcriptome. Cell 181:914-921

Kimberlin DW, Brady MT, Jackson MA, Long SS editors (2018) American Academy of Pediatrics. Coronaviruses, Including SARS and MERS:Section 3: Summaries of Infectious Diseases - C. Red Book: 2018 Report of the Committee on Infectious Diseases American Academy of Pediatrics

Kissler SM, Tedijanto C, Goldstein E, Grad YH, Lipsitch M (2020) Projecting the transmission dynamics of SARS-CoV-2 through the postpandemic period. Science 368:860-868

Klok FA, Kruip M, van der Meer NJM, Arbous MS, Gommers D, Kant KM, Kaptein FHJ, van Paassen J, Stals MAM, Huisman MV, Endeman H (2020) Incidence of thrombotic complications in critically ill ICU patients with COVID-19. Thromb Res 191:145-147

Klumperman J, Locker JK, Meijer A, Horzinek MC, Geuze HJ, Rottier PJ (1994) Coronavirus M proteins accumulate in the Golgi complex beyond the site of virion budding. J Virol 68:6523-6534

Kollias A, Kyriakoulis KG, Dimakakos E, Poulakou G, Stergiou GS, Syrigos K (2020) Thromboembolic risk and anticoagulant therapy in COVID-19 patients: emerging evidence and call for action. Br J Haematol 189:846-847

Kono M, Tatsumi K, Imai AM, Saito K, Kuriyama T, Shirasawa H (2008) Inhibition of human coronavirus 229E infection in human epithelial lung cells (L132) by chloroquine: involvement of p38 MAPK and ERK. Antivir Res 77:150-152

Lam TTY, Shum MHH, Zhu HC, Tong YG, Ni XB, Liao YS, Wei W, Cheung WYM, Li WJ, Li LF, Leung GM, Holmes EC, Hu YL, Guan Y (2020) Identifying SARS-CoV-2 related coronaviruses in Malayan pangolins. Nature

LaMonica M (2020) Donald Trump's 'Chinese virus': the politics of naming. The Conversation. https://theconversation.com/donaldtrumps-chinese-virus-the-politics-of-naming-136796

Lauer SA, Grantz KH, Bi Q, Jones FK, Zheng Q, Meredith HR, Azman AS, Reich NG, Lessler J (2020) The incubation period of coronavirus disease 2019 (COVID-19) from publicly reported confirmed cases: estimation and application. Ann Int Med 172:577-582
Lefkowitz EJ, Dempsey DM, Hendrickson RC, Orton RJ, Siddell SG, Smith DB (2018) Virus taxonomy: the database of the international committee on taxonomy of viruses (ICTV). Nucleic Acids Res 46: D708-D717

Lescure FX et al (2020) Clinical and virological data of the first cases of COVID-19 in Europe: a case series. Lancet Infect Dis 20:30200

Li F (2016) Structure, function, and evolution of Coronavirus spike proteins. Annu Rev Virol 3:237-261

Li F, Li W, Farzan M, Harrison SC (2005a) Structure of SARS coronavirus spike receptor-binding domain complexed with receptor. Science 309:1864-1868

Li W, Zhang C, Sui J, Kuhn JH, Moore MJ, Luo S, Wong SK, Huang IC, Xu K, Vasilieva N, Murakami A, He Y, Marasco WA, Guan Y, Choe H, Farzan M (2005b) Receptor and viral determinants of SARScoronavirus adaptation to human ACE2. EMBO J 24:1634-1643

Li Q et al (2020a) Early transmission dynamics in Wuhan, China, of Novel Coronavirus-infected pneumonia. N Engl J Med 382:11991207

Li YC, Bai WZ, Hashikawa T (2020b) The neuroinvasive potential of SARS-CoV2 may play a role in the respiratory failure of COVID-19 patients. J Med Virol 92:552-555

Lim KP, Liu DX (2001) The missing link in coronavirus assembly. Retention of the avian coronavirus infectious bronchitis virus envelope protein in the pre-Golgi compartments and physical interaction between the envelope and membrane proteins. J Biol Chem 276: $17515-17523$

Lim YX, Ng YL, Tam JP, Liu DX (2016) Human coronaviruses: a review of virus-host interactions. Diseases 4:26

Liu DX, Inglis SC (1991) Association of the infectious bronchitis virus 3c protein with the virion envelope. Virology 185:911-917

Liu $\mathrm{T}$ et al (2020) Time-varying transmission dynamics of novel coronavirus pneumonia in China. bioRxiv

$\mathrm{Lu} \mathrm{R}$ et al (2020a) Genomic characterisation and epidemiology of 2019 novel coronavirus: implications for virus origins and receptor binding. Lancet 395:565-574

Lu X et al (2020b) SARS-CoV-2 infection in children. N Engl J Med 382: $1663-1665$

Luk HKH, Li X, Fung J, Lau SKP, Woo PCY (2019) Molecular epidemiology, evolution and phylogeny of SARS coronavirus. Infect Genet Evol 71:21-30

Luo H, Chen Q, Chen J, Chen K, Shen X, Jiang H (2005) The nucleocapsid protein of SARS coronavirus has a high binding affinity to the human cellular heterogeneous nuclear ribonucleoprotein A1. FEBS Lett 579:2623-2628

Mackay IM, Arden KE (2015) MERS coronavirus: diagnostics, epidemiology and transmission. Virol J 12:222

Maier HJ, Hawes PC, Cottam EM, Mantell J, Verkade P, Monaghan P, Wileman T, Britton P (2013) Infectious bronchitis virus generates spherules from zippered endoplasmic reticulum membranes. $\mathrm{mBio}$ 4:e00801-e00813

Mandrola J (2020) CoViD-19 and PPE: some of us will die because of the shortage. Recenti Prog Med 111:183

Mao L, Jin H, Wang M, Hu Y, Chen S, He Q, Chang J, Hong C, Zhou Y, Wang D, Miao X, Li Y, Hu B (2020a) Neurologic manifestations of hospitalized patients with Coronavirus disease 2019 in Wuhan, China. JAMA Neurol 77:1-9

Mao R, Qiu Y, He JS, Tan JY, Li XH, Liang J, Shen J, Zhu LR, Chen Y, Iacucci M, Ng SC, Ghosh S, Chen MH (2020b) Manifestations and prognosis of gastrointestinal and liver involvement in patients with COVID-19: a systematic review and meta-analysis. Lancet Gastroenterol Hepatol 5:667-678

Marquardt K, Albertson TE (2001) Treatment of hydroxychloroquine overdose. Am J Emerg Med 19:420-424

Martinez-Rojas MA, Vega-Vega O, Bobadilla NA (2020) Is the kidney a target of SARS-CoV-2? Am J Physiol Renal Physiol 318:F1454 F1462 
Masters PS (2006) The molecular biology of coronaviruses. Adv Virus Res 66:193-292

McCreary EK, Pogue JM (2020) Coronavirus disease 2019 treatment: a review of early and emerging options. Open Forum Infect Dis 7: ofaal 05

Mercuro NJ, Yen CF, Shim DJ, Maher TR, McCoy CM, Zimetbaum PJ, Gold HS (2020) Risk of QT interval prolongation associated with use of hydroxychloroquine with or without concomitant azithromycin among hospitalized patients testing positive for coronavirus disease 2019 (COVID-19). JAMA Cardiol

Meselson M (2020) Droplets and aerosols in the transmission of SARSCoV-2. N Engl J Med 382:2063

Moore BJB, June CH (2020) Cytokine release syndrome in severe COVID-19. Science 368:473-474

Morawska L, Cao J (2020) Airborne transmission of SARS-CoV-2: the world should face the reality. Environ Int 139:105730

Moriguchi T et al (2020) A first case of meningitis/encephalitis associated with SARS-Coronavirus-2. Int J Infect Dis 94:55-58

Murray RS, Brown B, Brian D, Cabirac GF (1992) Detection of coronavirus RNA and antigen in multiple sclerosis brain. Ann Neurol 31: 525-533

Nakauchi M, Kariwa H, Kon Y, Yoshii K, Maeda A, Takashima I (2008) Analysis of severe acute respiratory syndrome coronavirus structural proteins in virus-like particle assembly. Microbiol Immunol 52:625630

Nanda SK, Leibowitz JL (2001) Mitochondrial aconitase binds to the 3' untranslated region of the mouse hepatitis virus genome. J Virol 75: $3352-3362$

National Center for Learning Disabilities (NCLD) (2020) COVID-19 parent resources. https://www.ncld.org/covid-19-parent-resources

Netland J, Meyerholz DK, Moore S, Cassell M, Perlman S (2008) Severe acute respiratory syndrome coronavirus infection causes neuronal death in the absence of encephalitis in mice transgenic for human ACE2. J Virol 82:7264-7275

Nicola M, Alsafi Z, Sohrabi C, Kerwan A, Al-Jabir A, Iosifidis C, Agha M, Agha R (2020) The socio-economic implications of the coronavirus and COVID-19 pandemic: a review. Int J Surg 78:185-193

Office of Disease Prevention and Health Promotion (ODPHP) (2020) Social determinants of health. https://www.healthypeople.gov/ 2020/topics-objectives/topic/social-determinants-of-health

Oxley TJ, Mocco J, Majidi S, Kellner CP, Shoirah H, Singh IP, De Leacy RA, Shigematsu T, Ladner TR, Yaeger KA, Skliut M, Weinberger J, Dangayach NS, Bederson JB, Tuhrim S, Fifi JT (2020) Large-vessel stroke as a presenting feature of Covid-19 in the Young. N Engl J Med 382:e60

Park MD (2020) Macrophages: a Trojan horse in COVID-19? Nat Rev Immunol 20:351

Pinto D, Windecker S, Cutlip D, Saperia G (2020) Coronavirus disease 2019 (COVID-19): myocardial infarction and other coronary artery disease issues. UpToDate

Poon DC, Ho YS, Chiu K, Wong HL, Chang RC (2015) Sickness: from the focus on cytokines, prostaglandins, and complement factors to the perspectives of neurons. Neurosci Biobehav Rev 57:30-45

Poyiadji N, Shahin G, Noujaim D, Stone M, Patel S, Griffith B (2020) COVID-19-associated acute hemorrhagic necrotizing encephalopathy: CT and MRI features. Radiology:201187

Prutkin J, Knight B, Downey B (2020) Coronavirus disease 2019 (COVID-19): arrhythmias and conduction system disease. UpToDate

Puelles VG et al (2020) Multiorgan and renal tropism of SARS-CoV-2. N Engl J Med

Pyrc K, Berkhout B, van der Hoek L (2007) The Novel human coronaviruses NL63 and HKU1. J Virol 81:3051-3057

Qinfen Z, Jinming C, Xiaojun H, Huanying Z, Jicheng H, Ling F, Kunpeng L, Jingqiang Z (2004) The life cycle of SARS coronavirus in Vero E6 cells. J Med Virol 73:332-337
Ranieri VM, Rubenfeld GD, Thompson BT, Ferguson ND, Caldwell E, Fan E, Camporota L, Slutsky AS (2012) Acute respiratory distress syndrome: the Berlin definition. JAMA 307:2526-2533

Ransom EM, Burnham C-AD, Jones L, Kraft CS, McDonald LC, Reinink AR, Young VB (2020) Fecal microbiota transplantations: where are we, where are we going, and what is the role of the clinical laboratory? Clin Chem 66:512-517

Read JM, Bridgen JR, Cummings DA, Ho A, Jewell CP (2020) Novel coronavirus 2019-nCoV: early estimation of epidemiological parameters and epidemic predictions. medRxiv

Reggiori F, Monastyrska I, Verheije MH, Cali T, Ulasli M, Bianchi S, Bernasconi R, de Haan CA, Molinari M (2010) Coronaviruses hijack the LC3-I-positive EDEMosomes, ER-derived vesicles exporting short-lived ERAD regulators, for replication. Cell Host Microbe 7:500-508

Ren LL et al (2020) Identification of a novel coronavirus causing severe pneumonia in human: a descriptive study. Chinese Med J 133:10151024

Rey FA, Lok SM (2018) Common features of enveloped viruses and implications for immunogen design for next-generation vaccines. Cell 172:1319-1334

Richardson S et al (2020) Presenting characteristics, comorbidities, and outcomes among 5700 patients hospitalized with COVID-19 in the New York City area. JAMA 323:2052-2059

Riou J, Althaus CL (2020) Pattern of early human-to-human transmission of Wuhan 2019 novel coronavirus (2019-nCoV), December 2019 to January 2020. Euro surveillance 25:2000058

Rodo X, Curcoll R, Robinson M, Ballester J, Burns JC, Cayan DR, Lipkin WI, Williams BL, Couto-Rodriguez M, Nakamura Y, Uehara R, Tanimoto H, Morgui JA (2014) Tropospheric winds from northeastern China carry the etiologic agent of Kawasaki disease from its source to Japan. Proc Natl Acad Sci U S A 111:7952-7957

Rogers JP, Chesney E, Oliver D, Pollak TA, McGuire P, Fusar-Poli P, Zandi MS, Lewis G, David AS (2020a) Psychiatric and neuropsychiatric presentations associated with severe coronavirus infections: a systematic review and meta-analysis with comparison to the COVID-19 pandemic. Lancet Psychiatry 7:611-627

Rogers K, Jakes L, Swanson A (2020b) Trump defends using 'Chinese virus' label, ignoring growing criticism. The New York Times. https://www.nytimes.com/2020/03/18/us/politics/china-virus.html

Rubens JH, Karakousis PC, Jain SK (2020) Stability and viability of SARS-CoV-2. N Engl J Med 382:1962-1963

Russo M (2020) Up to 5 NY children dead, 100 sickened by rare COVIDrelated illness. NBC New York. https://www.nbcnewyork.com/ investigations/kawasaki-disease-up-to-5-ny-children-dead-85sickened-by-rare-covid-related-illness/2411571/

Saad M, Omrani AS, Baig K, Bahloul A, Elzein F, Matin MA, Selim MA, Al Mutairi M, Al Nakhli D, Al Aidaroos AY, Al Sherbeeni N, AlKhashan HI, Memish ZA, Albarrak AM (2014) Clinical aspects and outcomes of 70 patients with Middle East respiratory syndrome coronavirus infection: a single-center experience in Saudi Arabia. Int J Infect Dis 29:301-306

Sanders JM, Monogue ML, Jodlowski TZ, Cutrell JB (2020) Pharmacologic treatments for coronavirus disease 2019 (COVID19): a review. JAMA

Schlosser E (2020) America's slaughterhouses Aren't just killing animals. The Atlantic. https://www.theatlantic.com/ideas/archive/2020/05/ essentials-meatpeacking-coronavirus/611437/

Schoeman D, Fielding BC (2019) Coronavirus envelope protein: current knowledge. Virol J 16:69

Schwamm LH, Erskine A, Licurse A (2020) A digital embrace to blunt the curve of COVID19 pandemic. NPJ Digit Med 3:64

Seeman TE (1996) Social ties and health: the benefits of social integration. Ann Epidemiol 6:442-451 
Shang J, Ye G, Shi K, Wan Y, Luo C, Aihara H, Geng Q, Auerbach A, Li F (2020) Structural basis of receptor recognition by SARS-CoV-2. Nature 581:221-224

Shen M, Peng Z, Xiao Y, Zhang L (2020) Modelling the epidemic trend of the 2019 novel coronavirus outbreak in China. bioRxiv

Siddamreddy S, Thotakura R, Dandu V, Kanuru S, Meegada S (2020) Corona virus disease 2019 (COVID-19) presenting as acute ST elevation myocardial infarction. Cureus 12:e7782

Singh AK, Bhushan B, Maurya A, Mishra G, Singh SK, Awasthi R (2020) Novel Coronavirus disease 2019 (COVID-19) and neurodegenerative disorders. Dermatol Ther:e13591

Siu YL, Teoh KT, Lo J, Chan CM, Kien F, Escriou N, Tsao SW, Nicholls JM, Altmeyer R, Peiris JS, Bruzzone R, Nal B (2008) The M, E, and $\mathrm{N}$ structural proteins of the severe acute respiratory syndrome coronavirus are required for efficient assembly, trafficking, and release of virus-like particles. J Virol 82:11318-11330

Song HC, Seo MY, Stadler K, Yoo BJ, Choo QL, Coates SR, Uematsu Y, Harada T, Greer CE, Polo JM, Pileri P, Eickmann M, Rappuoli R, Abrignani S, Houghton M, Han JH (2004) Synthesis and characterization of a native, oligomeric form of recombinant severe acute respiratory syndrome coronavirus spike glycoprotein. J Virol 78: 10328-10335

Song Y, Liu P, Shi XL, Chu YL, Zhang J, Xia J, Gao XZ, Qu T, Wang MY (2020) SARS-CoV-2 induced diarrhoea as onset symptom in patient with COVID-19. Gut 69:1143-1144

Spagnolo JF, Hogue BG (2000) Host protein interactions with the $3^{\prime}$ end of bovine coronavirus RNA and the requirement of the poly(A) tail for coronavirus defective genome replication. J Virol 74:5053-5065

Spychalski P, Błażyńska-Spychalska A, Kobiela J (2020) Estimating case fatality rates of COVID-19. Lancet Infect Dis 20:774-775

Srinivasan S, Cui H, Gao Z, Liu M, Lu S, Mkandawire W, Narykov O, Sun M, Korkin D (2020) Structural genomics of SARS-CoV-2 indicates evolutionary conserved functional regions of viral proteins. Viruses 12:360

Billboard Staff (2020) Here are all the major music events canceled due to coronavirus (updating). Billboard. https:/www.billboard.com/ articles/business/touring/9323647/concerts-canceled-coronaviruslist

Stancati M, Douglas J (2020) Doctors investigate link between rare childhood disease and Covid-19. The Wall Street Journal https://www. wsj.com/articles/doctors-investigate-link-between-rare-childhooddisease-and-covid-19-11588187103

Su H, Yang M, Wan C, Yi LX, Tang F, Zhu HY, Yi F, Yang HC, Fogo AB, Nie X, Zhang C (2020) Renal histopathological analysis of 26 postmortem findings of patients with COVID-19 in China. Kidney Int 98:219-227

Sui J, Li W, Murakami A, Tamin A, Matthews LJ, Wong SK, Moore MJ, Tallarico AS, Olurinde M, Choe H, Anderson LJ, Bellini WJ, Farzan M, Marasco WA (2004) Potent neutralization of severe acute respiratory syndrome (SARS) coronavirus by a human $\mathrm{mAb}$ to S1 protein that blocks receptor association. Proc Natl Acad Sci U S A 101: 2536-2541

Sultan S, Altayar O, Siddique SM, Davitkov P, Feuerstein JD, Lim JK, Falck-Ytter Y, El-Serag HB, Aga (2020) AGA Institute rapid review of the GI and liver manifestations of COVID-19, meta-analysis of international data, and recommendations for the Consultative Management of Patients with COVID-19. Gastroenterology

Sun X, Wang T, Cai D, Hu Z, Chen J, Liao H, Zhi L, Wei H, Zhang Z, Qiu Y, Wang J, Wang A (2020) Cytokine storm intervention in the early stages of COVID-19 pneumonia. Cytokine Growth Factor Rev 53: $38-42$

Tan YW, Hong W, Liu DX (2012) Binding of the 5'-untranslated region of coronavirus RNA to zinc finger CCHC-type and RNA-binding motif 1 enhances viral replication and transcription. Nucleic Acids Res 40:5065-5077
Tang N, Li D, Wang X, Sun Z (2020) Abnormal coagulation parameters are associated with poor prognosis in patients with novel coronavirus pneumonia. J Thromb Haemost 18:844-847

Tao C, Guang C, Wei G, Min X, Marco, Li Y, Suhua CFL (2020) A quick guide to the diagnosis and treatment of pneumonia for novel coronavirus infections (third edition). Herald Med 39:305-307 http:/ kns.cnki.net/kcms/detail/42.1293.r.20200130.1803.002.html

Tavazzi G, Pellegrini C, Maurelli M, Belliato M, Sciutti F, Bottazzi A, Sepe PA, Resasco T, Camporotondo R, Bruno R, Baldanti F, Paolucci S, Pelenghi S, Iotti GA, Mojoli F, Arbustini E (2020) Myocardial localization of coronavirus in COVID-19 cardiogenic shock. Eur J Heart Fail 22:911-915

Torales J, O'Higgins M, Castaldelli-Maia JM, Ventriglio A (2020) The outbreak of COVID-19 coronavirus and its impact on global mental health. Int J Soc Psychiatry 66:317-320

Toscano G, Palmerini F, Ravaglia S, Ruiz L, Invernizzi P, Cuzzoni MG, Franciotta D, Baldanti F, Daturi R, Postorino P, Cavallini A, Micieli G (2020) Guillain-Barre syndrome associated with SARS-CoV-2. N Engl J Med 382:2574-2576

Tsai J, Wilson M (2020) COVID-19: a potential public health problem for homeless populations. Lancet Public Health 5:e186-e187

U.S. Food and drug Administration (FDA) (2020) Coronavirus (COVID19) update: FDA issues emergency use authorization for potential COVID-19 treatment. https://www.fda.gov/news-events/pressannouncements/coronavirus-covid-19-update-fda-issuesemergency-use-authorization-potential-covid-19-treatment

van Doremalen N, Bushmaker T, Morris DH, Holbrook MG, Gamble A, Williamson BN, Tamin A, Harcourt JL, Thornburg NJ, Gerber SI, Lloyd-Smith JO, de Wit E, Munster VJ (2020) Aerosol and surface stability of SARS-CoV-2 as compared with SARS-CoV-1. N Engl J Med 382:1564-1567

Vandell P (2020) Pinal County sheriff mark lamb responds to testing positive for COVID-19, says he wouldn't enforce mask mandate. Azcentral. https://www.azcentral.com/story/news/local/arizonabreaking/2020/06/20/pinal-county-sheriff-mark-lamb-respondstesting-positive-covid-19-says-he-wouldnt-enforce-mask-manda/ 3230614001/

Verheije MH, Raaben M, Mari M, Te Lintelo EG, Reggiori F, van Kuppeveld FJ, Rottier PJ, de Haan CA (2008) Mouse hepatitis coronavirus RNA replication depends on GBF1-mediated ARF1 activation. PLoS Pathog 4:e1000088

Volz E et al (2020) Report 5: phylogenetic analysis of SARS-CoV-2. Imperial College London. Imperial College London COVID-19. https://doi.org/10.25561/77169

Vulture editors (2020) All the live events, movie releases, and productions affected by the Coronavirus. Vulture. https://www.vulture. com/2020/06/events-cancelled-coronavirus.html

Walls AC, Park YJ, Tortorici MA, Wall A, McGuire AT, Veesler D (2020) Structure, function, and antigenicity of the SARS-CoV-2 spike glycoprotein. Cell 181:281-292

Wan Y, Shang J, Graham R, Baric RS, Li F (2020) Receptor recognition by the Novel coronavirus from Wuhan: an analysis based on decadeLong structural studies of SARS coronavirus. J Virol 94:e00127$\mathrm{e} 00120$

Wang J, Fang S, Xiao H, Chen B, Tam JP, Liu DX (2009) Interaction of the coronavirus infectious bronchitis virus membrane protein with beta-actin and its implication in virion assembly and budding. PLoS One 4:e4908

Wang D, Hu B, Hu C, Zhu F, Liu X, Zhang J, Wang B, Xiang H, Cheng Z, Xiong Y, Zhao Y, Li Y, Wang X, Peng Z (2020a) Clinical characteristics of 138 hospitalized patients with 2019 Novel Coronavirusinfected pneumonia in Wuhan, China. JAMA 323:1061-1069

Wang Q, Zhang Y, Wu L, Niu S, Song C, Zhang Z, Lu G, Qiao C, Hu Y, Yuen KY, Wang Q, Zhou H, Yan J, Qi J (2020b) Structural and functional basis of SARS-CoV-2 entry by using human ACE2. Cell 181:894-904 
Wang W, Tang J, Wei F (2020c) Updated understanding of the outbreak of 2019 novel coronavirus (2019-nCoV) in Wuhan, China. J Med Virol 92:441-447

Wertheim JO, Chu DK, Peiris JS, Kosakovsky Pond SL, Poon LL (2013) A case for the ancient origin of coronaviruses. J Virol 87:7039-7045

Wong ACP, Li X, Lau SKP, Woo PCY (2019) Global epidemiology of bat coronaviruses. Viruses 11:174

Woo PC, Huang Y, Lau SK, Yuen KY (2010) Coronavirus genomics and bioinformatics analysis. Viruses 2:1804-1820

World Health Organization (2003) Summary of probable SARS cases with onset of illness from 1 November 2002 to 31 July 2003. https://www.who.int/csr/sars/country/table2004_04_21/en/

World Health Organization (2019) MERS situation update, December 2019. Epidemic and pandemic-prone diseases. http://www.emro. who.int/pandemic-epidemic-diseases/mers-cov/mers-situationupdate-december-2019.html

World Health Organization (2020a) Coronavirus disease (COVID-2019) situation reports. https://www.who.int/emergencies/diseases/novelcoronavirus-2019/situation-reports/

World Health Organization (2020b) Laboratory testing for coronavirus disease 2019 (COVID-19) in suspected human cases: interim guidance, 2 March 2020. https://apps.who.int/iris/handle/10665/331329

World Health Organization (2020c) WHO Timeline-COVID-19. https:// www.who.int/news-room/detail/27-04-2020-who-timeline\%2D\% 2D-covid-19

World Health Organization (2020d) Novel Coronavirus - China. Emergencies preparedness, response. https://www.who.int/csr/don/ 12-january-2020-novel-coronavirus-china/en/

World Health Organization (2020e) Novel Coronavirus - Thailand (exChina). Emergencies preparedness, response. https://www.who.int/ csr/don/14-january-2020-novel-coronavirus-thailand/en/

World Health Organization (2020f) Novel Coronavirus(2019-nCoV) Situation Report-10. https://www.who.int/docs/default-source/ coronaviruse/situation-reports/20200130-sitrep-10-ncov.pdf? sfvrsn=d0b2e480_2

World Health Organization (2020g) Novel Coronavirus(2019-nCoV) Situation Report-20. https://www.who.int/docs/default-source/ coronaviruse/situation-reports/20200209-sitrep-20-ncov.pdf? sfvrsn $=6 \mathrm{f} 80 \mathrm{~d} 1 \mathrm{~b} 94$

World Health Organization (2020h) Naming the coronavirus disease (COVID-19) and the virus that causes it. https://www.who.int/ emergencies/diseases/novel-coronavirus-2019/technical-guidance/ naming-the-coronavirus-disease-(covid-2019)-and-the-virus-thatcauses-it

World Health Organization (2020i) Coronavirus disease 2019 (COVID19) Situation Report-26. https://www.who.int/docs/default-source/ coronaviruse/situation-reports/20200215-sitrep-26-covid-19.pdf? sfvrsn=a4cc6787 2

World Health Organization (2020j) Coronavirus disease 2019 (COVID19) Situation Report-40. https://www.who.int/docs/default-source/ coronaviruse/situation-reports/20200229-sitrep-40-covid-19.pdf? sfvrsn $=849 \mathrm{~d} 06652$

World Health Organization (2020k) Coronavirus disease 2019 (COVID19) Situation Report-51. https://www.who.int/docs/default-source/ coronaviruse/situation-reports/20200311-sitrep-51-covid-19.pdf? sfvrsn=1ba62e $57 \quad 10$

World Health Organization (20201) Coronavirus disease 2019 (COVID19) Situation Report-59. https://www.who.int/docs/default-source/ coronaviruse/situation-reports/20200319-sitrep-59-covid-19.pdf? sfvrsn=c3dedef9 2

World Health Organization (2020m) Coronavirus disease 2019 (COVID19) Situation Report-62. https://www.who.int/docs/default-source/ coronaviruse/situation-reports/20200322-sitrep-62-covid-19.pdf? sfvrsn $=755 \mathrm{c} 76 \mathrm{~cd} 2$

World Health Organization (2020n) Coronavirus disease 2019 (COVID19) Situation Report-67. https://www.who.int/docs/default-source/ coronaviruse/situation-reports/20200327-sitrep-67-covid-19.pdf? sfvrsn=b65f68eb 4

World Health Organization (2020o) Coronavirus disease 2019 (COVID19) Situation Report-69. https://www.who.int/docs/default-source/ coronaviruse/situation-reports/20200329-sitrep-69-covid-19.pdf? sfvrsn $=8 \mathrm{~d} 6620 \mathrm{fa} \_8$

World Health Organization (2020p) Coronavirus disease 2019 (COVID19) Situation Report-72. https://www.who.int/docs/default-source/ coronaviruse/situation-reports/20200401-sitrep-72-covid-19.pdf? sfvrsn $=3 \mathrm{dd} 8971 \mathrm{~b} 2$

World Health Organization (2020q) Coronavirus disease 2019 (COVID19) Situation Report-76. https://www.who.int/docs/default-source/ coronaviruse/situation-reports/20200405-sitrep-76-covid-19.pdf? sfvrsn=6ecf0977 4

World Health Organization (2020r) Coronavirus disease 2019 (COVID19) Situation Report-86. https://www.who.int/docs/default-source/ coronaviruse/situation-reports/20200415-sitrep-86-covid-19.pdf? sfvrsn=c615ea20_6

World Health Organization (2020s) Coronavirus disease 2019 (COVID19) Situation Report-96. https://www.who.int/docs/default-source/ coronaviruse/situation-reports/20200425-sitrep-96-covid-19.pdf? sfvrsn=a33836bb_4

World Health Organization (2020t) Coronavirus disease 2019 (COVID19) Situation Report-98. https://www.who.int/docs/default-source/ coronaviruse/situation-reports/20200427-sitrep-98-covid-19.pdf? sfvrsn $=90323472 \quad 4$

World Health Organization (2020u) Coronavirus disease (COVID-19) Situation Report-126. https://www.who.int/docs/default-source/ coronaviruse/situation-reports/20200525-covid-19-sitrep-126.pdf? sfvrsn $=887 \mathrm{dbd} 662$

World Health Organization (2020v) Coronavirus disease (COVID-19) Situation Report-128. https://www.who.int/docs/default-source/ coronaviruse/situation-reports/20200527-covid-19-sitrep-128.pdf? sfvrsn=11720c0a 2

World Health Organization (2020w) Coronavirus disease (COVID-19) advice for the public. https://www.who.int/emergencies/diseases/ novel-coronavirus-2019/advice-for-public

Worldometer (2020a) COVID-19 CORONAVIRUS PANDEMIC. https://www.worldometers.info/coronavirus/

Worldometer (2020b) Coronavirus Cases: Itely. https://www. worldometers.info/coronavirus/country/italy/.

Worldometer (2020c) Coronavirus Cases: United States. https://www. worldometers.info/coronavirus/country/us/

Worldometer (2020d) Coronavirus Cases: Spain. https://www. worldometers.info/coronavirus/country/spain/

Worldometer (2020e) Coronavirus Cases: UK. https://www. worldometers.info/coronavirus/country/uk/

Wrapp D, Wang N, Corbett KS, Goldsmith JA, Hsieh CL, Abiona O, Graham BS, McLellan JS (2020) Cryo-EM structure of the 2019nCoV spike in the prefusion conformation. Science 367:1260-1263

Wu CH, Yeh SH, Tsay YG, Shieh YH, Kao CL, Chen YS, Wang SH, Kuo TJ, Chen DS, Chen PJ (2009) Glycogen synthase kinase-3 regulates the phosphorylation of severe acute respiratory syndrome coronavirus nucleocapsid protein and viral replication. J Biol Chem 284: 5229-5239

Wu CH, Chen PJ, Yeh SH (2014) Nucleocapsid phosphorylation and RNA helicase DDX1 recruitment enables coronavirus transition from discontinuous to continuous transcription. Cell Host Microbe $16: 462-472$

Wu C, Liu Y, Yang Y, Zhang P, Zhong W, Wang Y, Wang Q, Xu Y, Li M, Li X, Zheng M, Chen L, Li H (2020a) Analysis of therapeutic targets for SARS-CoV-2 and discovery of potential drugs by computational methods. Acta Pharm Sin B 10:766-788

Wu JT, Leung K, Leung GM (2020b) Nowcasting and forecasting the potential domestic and international spread of the 2019-nCoV 
outbreak originating in Wuhan, China: a modelling study. Lancet 395:689-697

Wu R, Wang L, Kuo HD, Shannar A, Peter R, Chou PJ, Li S, Hudlikar R, Liu X, Liu Z, Poiani GJ, Amorosa L, Brunetti L, Kong AN (2020c) An update on current therapeutic drugs treating COVID-19. Curr Pharmacol Rep:1-15

Xiao F, Sun J, Xu Y, Li F, Huang X, Li H, Zhao J, Huang J, Zhao J (2020) Infectious SARS-CoV-2 in feces of patient with severe COVID-19. Emerg Infect Dis 26

Xu S, Li Y (2020) Beware of the second wave of COVID-19. Lancet 395: $1321-1322$

Xu X, Liu Y, Weiss S, Arnold E, Sarafianos SG, Ding J (2003) Molecular model of SARS coronavirus polymerase: implications for biochemical functions and drug design. Nucleic Acids Res 31:7117-7130

Yamin M (2020) Counting the cost of COVID-19. Int J Inf Technol:1-7

Yan R, Zhang Y, Li Y, Xia L, Guo Y, Zhou Q (2020) Structural basis for the recognition of SARS-CoV-2 by full-length human ACE2. Science 367:1444-1448

Yancy CW (2020) COVID-19 and African Americans. JAMA

Yang X, Yu Y, Xu J, Shu H, Xia J, Liu H, Wu Y, Zhang L, Yu Z, Fang M, Yu T, Wang Y, Pan S, Zou X, Yuan S, Shang Y (2020) Clinical course and outcomes of critically ill patients with SARS-CoV-2 pneumonia in Wuhan, China: a single-centered, retrospective, observational study. Lancet Respir Med 8:475-481

Ye G, Lin H, Chen S, Wang S, Zeng Z, Wang W, Zhang S, Rebmann T, Li Y, Pan Z, Yang Z, Wang Y, Wang F, Qian Z, Wang X (2020a) Environmental contamination of SARS-CoV-2 in healthcare premises. J Inf Secur

Ye ZW, Yuan S, Yuen KS, Fung SY, Chan CP, Jin DY (2020b) Zoonotic origins of human coronaviruses. Int J Biol Sci 16:1686-1697

Yuki K, Fujiogi M, Koutsogiannaki S (2020) COVID-19 pathophysiology: a review. Clin Immunol 215:108427

Zaki AM, van Boheemen S, Bestebroer TM, Osterhaus AD, Fouchier RA (2012) Isolation of a novel coronavirus from a man with pneumonia in Saudi Arabia. N Engl J Med 367:1814-1820

Zeng JH, Liu YX, Yuan J, Wang FX, Wu WB, Li JX, Wang LF, Gao H, Wang Y, Dong CF, Li YJ, Xie XJ, Feng C, Liu L (2020) First case of COVID-19 complicated with fulminant myocarditis: a case report and insights. Infection

Zhang X, Shi H, Chen J, Shi D, Dong H, Feng L (2015) Identification of the interaction between vimentin and nucleocapsid protein of transmissible gastroenteritis virus. Virus Res 200:56-63

Zhang SF, Tuo JL, Huang XB, Zhu X, Zhang DM, Zhou K, Yuan L, Luo HJ, Zheng BJ, Yuen KY, Li MF, Cao KY, Xu L (2018) Epidemiology characteristics of human coronaviruses in patients with respiratory infection symptoms and phylogenetic analysis of HCoV-OC43 during 2010-2015 in Guangzhou. PLoS One 13: e0191789

Zhang B, Zhou X, Zhu C, Feng F, Qiu Y, Feng J, Jia Q, Song Q, Zhu B, Wang J (2020a) Immune phenotyping based on neutrophil-tolymphocyte ratio and IgG predicts disease severity and outcome for patients with COVID-19. medRxiv

Zhang C, Wu Z, Li J-W, Zhao H, Wang G-Q (2020b) The cytokine release syndrome (CRS) of severe COVID-19 and Interleukin-6 receptor (IL-6R) antagonist tocilizumab may be the key to reduce the mortality. Int J Antimicrob Agents 55:105954-105954

Zhang L, Lin D, Sun X, Curth U, Drosten C, Sauerhering L, Becker S, Rox K, Hilgenfeld R (2020c) Crystal structure of SARS-CoV-2 main protease provides a basis for design of improved alphaketoamide inhibitors. Science 368:409-412

Zhang W, Du RH, Li B, Zheng XS, Yang XL, Hu B, Wang YY, Xiao GF, Yan B, Shi ZL, Zhou P (2020d) Molecular and serological investigation of 2019-nCoV infected patients: implication of multiple shedding routes. Emerg Microbes Infect 9:386-389

Zhao H, Shen D, Zhou H, Liu J, Chen S (2020) Guillain-Barre syndrome associated with SARS-CoV-2 infection: causality or coincidence? Lancet Neurol 19:383-384

Zheng J, Yamada Y, Fung TS, Huang M, Chia R, Liu DX (2018) Identification of N-linked glycosylation sites in the spike protein and their functional impact on the replication and infectivity of coronavirus infectious bronchitis virus in cell culture. Virology 513: $65-74$

Zhong R (2020) The Coronavirus exposes education's digital divide. The New York Times. https://www.nytimes.com/2020/03/17/ technology/china-schools-coronavirus.html

Zhou B, She J, Wang Y, Ma X (2020a) A case of coronavirus disease 2019 with concomitant acute cerebral infarction and deep vein thrombosis. Front Neurol 11:296

Zhou F, Yu T, Du R, Fan G, Liu Y, Liu Z, Xiang J, Wang Y, Song B, Gu X, Guan L, Wei Y, Li H, Wu X, Xu J, Tu S, Zhang Y, Chen H, Cao B (2020b) Clinical course and risk factors for mortality of adult inpatients with COVID-19 in Wuhan, China: a retrospective cohort study. Lancet 395:1054-1062

Zhou P et al (2020c) A pneumonia outbreak associated with a new coronavirus of probable bat origin. Nature 579:270-273

Zhou Y, Hou Y, Shen J, Huang Y, Martin W, Cheng F (2020d) Networkbased drug repurposing for novel coronavirus 2019-nCoV/SARSCoV-2. Cell Discov 6:14

Zhu H, Wei L, Niu P (2020a) The novel coronavirus outbreak in Wuhan, China. Glob Health Res Policy 5:6

Zhu N, Zhang D, Wang W, Li X, Yang B, Song J, Zhao X, Huang B, Shi W, Lu R, Niu P, Zhan F, Ma X, Wang D, Xu W, Wu G, Gao GF, Tan W, China Novel Coronavirus I, Research T (2020b) A Novel Coronavirus from patients with pneumonia in China, 2019. N Engl J Med 382:727-733

Ziebuhr J (2005) In: Enjuanes L (ed) Coronavirus replication and reverse genetics, pp 57-94

Ziebuhr J, Snijder EJ, Gorbalenya AE (2000) Virus-encoded proteinases and proteolytic processing in the Nidovirales. J Gen Virol 81:853879

Zumla A, Chan JF, Azhar EI, Hui DS, Yuen KY (2016) Coronaviruses drug discovery and therapeutic options. Nat Rev Drug Discov 15: 327-347

Zuniga S, Sola I, Moreno JL, Sabella P, Plana-Duran J, Enjuanes L (2007) Coronavirus nucleocapsid protein is an RNA chaperone. Virology $357: 215-227$

Zuniga S, Cruz JL, Sola I, Mateos-Gomez PA, Palacio L, Enjuanes L (2010) Coronavirus nucleocapsid protein facilitates template switching and is required for efficient transcription. J Virol 84: 2169-2175

Publisher's Note Springer Nature remains neutral with regard to jurisdictional claims in published maps and institutional affiliations. 